\title{
Experimental and theoretical cross section data of deuteron induced nuclear reactions on platinum
}

\author{
F. Tárkányi ${ }^{1} \cdot$ F. Ditrói ${ }^{1}\left[\right.$ D. S. Takács ${ }^{1} \cdot$ A. Hermanne ${ }^{2} \cdot$ A. V. Ignatyuk ${ }^{3}$
}

Received: 30 April 2019 / Published online: 28 June 2019

(c) The Author(s) 2019

\begin{abstract}
Additional experimental activation cross sections for deuteron induced reactions on platinum were measured in the 35-49 MeV energy range for the ${ }^{\text {natt }} \mathrm{Pt}(\mathrm{d}, \mathrm{xn}){ }^{191,192,193,194,195,196 \mathrm{~m} 2,196 \mathrm{~g}, 198 \mathrm{~m}, 198 \mathrm{~g}, 199} \mathrm{Au},{ }^{\text {nat }} \mathrm{Pt}(\mathrm{d}, \mathrm{x}){ }^{189,191,193 \mathrm{~m}, 195 \mathrm{~m}, 197 \mathrm{~g}} \mathrm{Pt}$ and ${ }^{\text {nat }}$ $\mathrm{Pt}(\mathrm{d}, \mathrm{x})^{188,189,190 \mathrm{~m} 2,190,192,194 \mathrm{~m} 2} \mathrm{Ir}$ reactions by using the stacked foil irradiation technique and gamma ray spectrometry. The available experimental results are compared with the calculated values based on ALICE-D and EMPIRE-D model codes and with the theoretical predictions in the TALYS based TENDL-2017 library.
\end{abstract}

Keywords Platinum targets $\cdot$ Stacked foil technique $\cdot$ Deuteron induced reactions $\cdot$ Theoretical nuclear reaction model codes $\cdot \mathrm{Pt}, \mathrm{Au}$ and $\mathrm{Ir}$ radioisotopes $\cdot$ Thin layer activation

\section{Introduction}

Experimental activation cross section data of proton and deuteron induced reactions on platinum for production of medically relevant radioisotopes, for thin layer activation technology and for generally used activation data libraries [1-6] were reported by us earlier. The goal of this study was to clear the disagreement in our earlier measurement, and to compare all data with different theoretical models. Furthermore, we could determine new cross section for some reactions.

In our last investigation up to $50 \mathrm{MeV}$ [6] we could deduce only scattered data for some activation products and for some reactions significant disagreements were found with earlier experimental data. During a recent investigation of activation data on other target elements we got the possibility to obtain additional results on platinum in the 35-49 MeV energy range. In the present report, we compare the new data with the literature values and in order

F. Ditrói

ditroi@atomki.mta.hu

1 Institute for Nuclear Research, Hungarian Academy of Sciences (ATOMKI), Debrecen, Hungary

2 Cyclotron Laboratory, Vrije Universiteit Brussel (VUB), Brussels, Belgium

3 Institute of Physics and Power Engineering (IPPE), Obninsk, Russia 249020 to investigate the prediction capability of theoretical results we made calculations with the ALICE and EMPIRE codes, modified to better represent deuteron induced reactions.

\section{Experimental details and data analysis}

Elemental experimental cross sections were determined by using the activation method, stacked foil irradiation technique and HPGe gamma ray spectrometry. Cross-section data were deduced relative to the excitation functions of the ${ }^{27} \mathrm{Al}(\mathrm{d}, \mathrm{x}){ }^{22,24} \mathrm{Na}$ monitor reactions [7] re-measured in the whole covered energy range.

The irradiation was made at an external beam line of the Cyclone 90 cyclotron of the Université Catholique in Louvain la Neuve (LLN) for 60 min with a $50 \mathrm{MeV}$ energy extracted beam having $100 \mathrm{nA}$ beam intensity. The targets were irradiated in a short Faraday cup.

The irradiated stack contained a sequence of 7 blocks of $\mathrm{Hf}(10.54 \mu \mathrm{m}), \mathrm{Al}(49.54 \mu \mathrm{m}), \mathrm{Al}(49.54 \mu \mathrm{m}), \mathrm{Pt}(19.29 \mu \mathrm{m})$, $\mathrm{Al}(49.54 \mu \mathrm{m}), \mathrm{Al}(49.54 \mu \mathrm{m}), \mathrm{CuMnNi}$ alloy $(24.73 \mu \mathrm{m})$, $\mathrm{Al}(49.54 \mu \mathrm{m}), \mathrm{Al}(49.54 \mu \mathrm{m})$ followed by 13 blocks of $\mathrm{Hf}$ $(10.54 \mu \mathrm{m}) \mathrm{Al}(10.85 \mu \mathrm{m}), \mathrm{Al}(49.54 \mu \mathrm{m}), \mathrm{CuMnNi}$ alloy $(24.73 \mu \mathrm{m})$ and $\mathrm{Al}(10.85 \mu \mathrm{m})$. The $7 \mathrm{Pt}$ targets covered the 49-35 MeV energy range.

Four series of gamma-ray spectra were measured to follow the decay, starting at 7.9-8.7 h, 21.3-25.1 h, 187.2-198.2 $\mathrm{h}$ and 2811.1-3022.9 $\mathrm{h}$ after the end of 
Table 1 Decay characteristic of the investigated reaction products and Q-values of the contributing processes

\begin{tabular}{|c|c|c|c|c|c|}
\hline $\begin{array}{l}\text { Nuclide spin/parity } \\
\text { decay level energy }\end{array}$ & Half-life & $\mathrm{E}_{\gamma(\mathrm{keV})}$ & $\mathrm{I}(\%)$ & Contributing process & $Q$-value $(\mathrm{MeV})$ \\
\hline $\begin{array}{l}{ }^{191 \mathrm{~g}} \mathrm{Au} \\
3 / 2^{+} \\
\varepsilon: 100 \%\end{array}$ & $3.18 \mathrm{~h}$ & $\begin{array}{l}277.86 \\
399.84 \\
478.04 \\
586.44 \\
674.22\end{array}$ & $\begin{array}{l}6.4 \\
4.2 \\
3.5 \\
15.0 \\
6.0\end{array}$ & $\begin{array}{l}{ }^{190} \mathrm{Pt}(\mathrm{d}, \mathrm{n}) \\
{ }^{192} \mathrm{Pt}(\mathrm{d}, 3 \mathrm{n}) \\
{ }^{194} \mathrm{Pt}(\mathrm{d}, 5 \mathrm{n}) \\
{ }^{195} \mathrm{Pt}(\mathrm{d}, 6 \mathrm{n}) \\
{ }^{196} \mathrm{Pt}(\mathrm{d}, 7 \mathrm{n}) \\
{ }^{198} \mathrm{Pt}(\mathrm{d}, 9 \mathrm{n})\end{array}$ & $\begin{array}{l}1.55 \\
-13.56 \\
-28.17 \\
-34.28 \\
-42.20 \\
-55.60\end{array}$ \\
\hline $\begin{array}{l}{ }^{192} \mathrm{Au} \\
1^{-} \\
\varepsilon: 100 \%\end{array}$ & $4.94 \mathrm{~h}$ & $\begin{array}{l}295.96 \\
308.46 \\
316.51 \\
612.46\end{array}$ & $\begin{array}{l}23 \\
3.5 \\
59 \\
4.4\end{array}$ & $\begin{array}{l}{ }^{192} \mathrm{Pt}(\mathrm{d}, 2 \mathrm{n}) \\
{ }^{194} \mathrm{Pt}(\mathrm{d}, 4 \mathrm{n}) \\
{ }^{195} \mathrm{Pt}(\mathrm{d}, 5 \mathrm{n}) \\
{ }^{196} \mathrm{Pt}(\mathrm{d}, 6 \mathrm{n}) \\
{ }^{198} \mathrm{Pt}(\mathrm{d}, 8 \mathrm{n})\end{array}$ & $\begin{array}{l}-6.52 \\
-21.14 \\
-27.24 \\
-35.16 \\
-48.56\end{array}$ \\
\hline $\begin{array}{l}{ }^{193 \mathrm{~g}} \mathrm{Au} \\
3 / 2^{+} \\
\varepsilon: 100 \%\end{array}$ & $17.65 \mathrm{~h}$ & $\begin{array}{l}112.52 \\
173.52 \\
255.57 \\
268.22 \\
439.04\end{array}$ & $\begin{array}{l}2.2 \\
2.7 \\
6.2 \\
3.6 \\
1.78\end{array}$ & $\begin{array}{l}{ }^{192} \mathrm{Pt}(\mathrm{d}, \mathrm{n}) \\
{ }^{194} \mathrm{Pt}(\mathrm{d}, 3 \mathrm{n}) \\
{ }^{195} \mathrm{Pt}(\mathrm{d}, 4 \mathrm{n}) \\
{ }^{196} \mathrm{Pt}(\mathrm{d}, 5 \mathrm{n}) \\
{ }^{198} \mathrm{Pt}(\mathrm{d}, 7 \mathrm{n})\end{array}$ & $\begin{array}{l}-6.52 \\
-12.43 \\
-18.54 \\
-26.46 \\
-39.86\end{array}$ \\
\hline $\begin{array}{l}{ }^{194} \mathrm{Au} \\
1^{-} \\
\varepsilon: 100 \%^{-}\end{array}$ & $38.02 \mathrm{~h}$ & $\begin{array}{l}293.55 \\
328.46 \\
1468.88\end{array}$ & $\begin{array}{l}10.58 \\
60.4 \\
6.61\end{array}$ & $\begin{array}{l}{ }^{194} \mathrm{Pt}(\mathrm{d}, 2 \mathrm{n}) \\
{ }^{195} \mathrm{Pt}(\mathrm{d}, 3 \mathrm{n}) \\
{ }^{196} \mathrm{Pt}(\mathrm{d}, 4 \mathrm{n}) \\
{ }^{198} \mathrm{Pt}(\mathrm{d}, 6 \mathrm{n})\end{array}$ & $\begin{array}{l}-5.56 \\
-11.66 \\
-19.58 \\
-32.98\end{array}$ \\
\hline $\begin{array}{l}{ }^{195 \mathrm{~g}} \mathrm{Au} \\
3 / 2^{+} \\
\varepsilon: 100 \%\end{array}$ & $186.01 \mathrm{~d}$ & $\begin{array}{r}98.86 \\
129.74\end{array}$ & $\begin{array}{l}11.21 \\
0.84\end{array}$ & $\begin{array}{l}{ }^{194} \mathrm{Pt}(\mathrm{d}, \mathrm{n}) \\
{ }^{195} \mathrm{Pt}(\mathrm{d}, 2 \mathrm{n}) \\
{ }^{196} \mathrm{Pt}(\mathrm{d}, 3 \mathrm{n}) \\
{ }^{198} \mathrm{Pt}(\mathrm{d}, 5 \mathrm{n})\end{array}$ & $\begin{array}{l}2.87 \\
-3.23 \\
-11.15 \\
-24.56\end{array}$ \\
\hline $\begin{array}{l}{ }^{196 \mathrm{~m} 2} \mathrm{Au} \\
12^{-} \\
\text {IT: } 100 \% \\
595.66 \mathrm{keV}\end{array}$ & $9.6 \mathrm{~h}$ & $\begin{array}{l}147.81 \\
168.37 \\
188.27\end{array}$ & $\begin{array}{l}43.5 \\
7.8 \\
30.0\end{array}$ & $\begin{array}{l}{ }^{195} \mathrm{Pt}(\mathrm{d}, \mathrm{n}) \\
{ }^{196} \mathrm{Pt}(\mathrm{d}, 2 \mathrm{n}) \\
{ }^{198} \mathrm{Pt}(\mathrm{d}, 4 \mathrm{n})\end{array}$ & $\begin{array}{l}3.41 \\
-4.51 \\
-17.92\end{array}$ \\
\hline $\begin{array}{l}{ }^{196 \mathrm{~g}} \mathrm{Au} \\
2^{-} \\
\beta^{-}: 7.0 \% \\
\varepsilon: 93.0 \%\end{array}$ & $6.1669 \mathrm{~d}$ & $\begin{array}{l}333.03 \\
355.73\end{array}$ & $\begin{array}{l}22.9 \\
87\end{array}$ & $\begin{array}{l}{ }^{195} \mathrm{Pt}(\mathrm{d}, \mathrm{n}) \\
{ }^{196} \mathrm{Pt}(\mathrm{d}, 2 \mathrm{n}) \\
{ }^{198} \mathrm{Pt}(\mathrm{d}, 4 \mathrm{n})\end{array}$ & $\begin{array}{l}3.41 \\
-4.51 \\
-17.92\end{array}$ \\
\hline $\begin{array}{l}{ }^{198 \mathrm{~m}} \mathrm{Au} \\
12^{-} \\
\text {IT: } 100 \% \\
811.7 \mathrm{keV}\end{array}$ & $2.272 \mathrm{~d}$ & $\begin{array}{r}97.21 \\
180.31 \\
204.10 \\
214.89 \\
333.82\end{array}$ & $\begin{array}{l}69 \\
49 \\
39 \\
77.3 \\
18\end{array}$ & ${ }^{198} \mathrm{Pt}(\mathrm{d}, 2 \mathrm{n})$ & -3.33 \\
\hline $\begin{array}{l}{ }^{198 \mathrm{~g}} \mathrm{Au} \\
2^{-} \\
\beta^{-}: 100 \%\end{array}$ & $2.6947 \mathrm{~d}$ & 411.80 & 95.62 & ${ }^{198} \mathrm{Pt}(\mathrm{d}, 2 \mathrm{n})$ & -3.33 \\
\hline $\begin{array}{l}{ }^{199} \mathrm{Au} \\
3 / 2^{+} \\
\beta^{-}: 100 \%\end{array}$ & $3.139 \mathrm{~d}$ & $\begin{array}{l}158.38 \\
208.20\end{array}$ & $\begin{array}{l}40.0 \\
8.72\end{array}$ & ${ }^{198} \operatorname{Pt}(\mathrm{d}, \mathrm{n})$ & 4.254 \\
\hline $\begin{array}{l}{ }^{188} \mathrm{Pt} \\
0^{+} \\
\alpha: 2.6 \mathrm{E}-5 \% \\
\varepsilon: 99.9999 \%\end{array}$ & $10.2 \mathrm{~d}$ & $\begin{array}{l}187.59 \\
195.05 \\
381.43 \\
423.34\end{array}$ & $\begin{array}{l}19.4 \\
18.6 \\
7.5 \\
4.4\end{array}$ & $\begin{array}{l}{ }^{190} \operatorname{Pt}(\mathrm{d}, \mathrm{p} 3 \mathrm{n}) \\
{ }^{192} \operatorname{Pt}(\mathrm{d}, \mathrm{p} 5 \mathrm{n}) \\
{ }^{194} \operatorname{Pt}(\mathrm{d}, \mathrm{p} 7 \mathrm{n})\end{array}$ & $\begin{array}{l}-17.86 \\
-32.97 \\
-47.59\end{array}$ \\
\hline $\begin{array}{l}{ }^{189} \mathrm{Pt} \\
3 / 2^{-} \\
\varepsilon: 100 \%\end{array}$ & $10.87 \mathrm{~h}$ & $\begin{array}{l}243.50 \\
568.85 \\
721.38\end{array}$ & $\begin{array}{l}7.0 \\
7.1 \\
9.3\end{array}$ & $\begin{array}{l}{ }^{190} \mathrm{Pt}(\mathrm{d}, \mathrm{p} 2 \mathrm{n}) \\
{ }^{192} \mathrm{Pt}(\mathrm{d}, \mathrm{p} 4 \mathrm{n}) \\
{ }^{194} \mathrm{Pt}(\mathrm{d}, \mathrm{p} 6 \mathrm{n}) \\
{ }^{195} \mathrm{Pt}(\mathrm{d}, \mathrm{p} 7 \mathrm{n})\end{array}$ & $\begin{array}{l}-11.14 \\
-26.24 \\
-40.86 \\
-46.96\end{array}$ \\
\hline $\begin{array}{l}{ }^{191} \mathrm{Pt} \\
3 / 2^{-} \\
\varepsilon: 100 \%\end{array}$ & $2.802 \mathrm{~d}$ & $\begin{array}{c}96.517 \\
129.42 \\
172.18 \\
351.21 \\
359.90 \\
409.44 \\
538.90\end{array}$ & $\begin{array}{l}3.28 \\
3.2 \\
3.52 \\
3.36 \\
6.0 \\
8.0 \\
13.7\end{array}$ & $\begin{array}{l}{ }^{190} \operatorname{Pt}(\mathrm{d}, \mathrm{p}) \\
{ }^{192} \operatorname{Pt}(\mathrm{d}, \mathrm{p} 2 \mathrm{n}) \\
{ }^{194} \operatorname{Pt}(\mathrm{d}, \mathrm{p} 4 \mathrm{n}) \\
{ }^{195} \operatorname{Pt}(\mathrm{d}, \mathrm{p} 5 \mathrm{n}) \\
{ }^{196} \operatorname{Pt}(\mathrm{d}, \mathrm{p} 6 \mathrm{n})\end{array}$ & $\begin{array}{l}4.22 \\
-10.89 \\
-25.50 \\
-31.60 \\
-39.53\end{array}$ \\
\hline
\end{tabular}


Table 1 (continued)

\begin{tabular}{|c|c|c|c|c|c|}
\hline $\begin{array}{l}\text { Nuclide spin/parity } \\
\text { decay level energy }\end{array}$ & Half-life & $\mathrm{E}_{\gamma(\mathrm{keV})}$ & $\mathrm{I}(\%)$ & Contributing process & $Q$-value $(\mathrm{MeV})$ \\
\hline $\begin{array}{l}193 \mathrm{~m} P t \\
13 / 2^{+} \\
\text {IT: } 100 \% \\
149.78 \mathrm{keV}\end{array}$ & $4.33 \mathrm{~d}$ & 135.50 & 0.112 & $\begin{array}{l}{ }^{192} \mathrm{Pt}(\mathrm{d}, \mathrm{p}) \\
{ }^{194} \mathrm{Pt}(\mathrm{d}, \mathrm{p} 2 \mathrm{n}) \\
{ }^{195} \mathrm{Pt}(\mathrm{d}, \mathrm{p} 3 \mathrm{n}) \\
{ }^{196} \mathrm{Pt}(\mathrm{d}, \mathrm{p} 4 \mathrm{n}) \\
{ }^{198} \mathrm{Pt}(\mathrm{d}, \mathrm{p} 6 \mathrm{n})\end{array}$ & $\begin{array}{l}4.04 \\
-10.58 \\
-16.68 \\
-24.60 \\
-38.01\end{array}$ \\
\hline $\begin{array}{l}{ }_{195 \mathrm{~m}} \mathrm{Pt} \\
13 / 2^{+} \\
\text {IT: } 100 \% \\
259.29 \mathrm{keV}\end{array}$ & $4.010 \mathrm{~d}$ & $\begin{array}{r}98.90 \\
129.79\end{array}$ & $\begin{array}{l}11.7 \\
2.90\end{array}$ & $\begin{array}{l}{ }^{194} \mathrm{Pt}(\mathrm{d}, \mathrm{p}) \\
{ }^{195} \mathrm{Pt}(\mathrm{d}, \mathrm{pn}) \\
{ }^{196} \mathrm{Pt}(\mathrm{d}, \mathrm{p} 2 \mathrm{n}) \\
{ }^{198} \mathrm{Pt}(\mathrm{d}, \mathrm{p} 4 \mathrm{n})\end{array}$ & $\begin{array}{l}3.88 \\
-22.25 \\
-10.15 \\
-23.55\end{array}$ \\
\hline $\begin{array}{l}{ }^{197 \mathrm{~m}} \mathrm{Pt} \\
13 / 2^{+} \\
\beta^{-}: 3.3 \% \\
\text { IT: } 96.7 \% \\
399.59 \mathrm{keV}\end{array}$ & $95.41 \mathrm{~min}$ & 346.5 & 11.1 & $\begin{array}{l}{ }^{196} \operatorname{Pt}(\mathrm{d}, \mathrm{p}) \\
{ }^{198} \operatorname{Pt}(\mathrm{d}, \mathrm{p} 2 \mathrm{n})\end{array}$ & $\begin{array}{l}3.62 \\
-9.78\end{array}$ \\
\hline $\begin{array}{l}{ }^{197 \mathrm{~g}} \mathrm{Pt} \\
1 / 2^{+} \\
\beta^{-}: 100 \%\end{array}$ & $19.89 \mathrm{~h}$ & 191.44 & 3.7 & $\begin{array}{l}{ }^{196} \operatorname{Pt}(\mathrm{d}, \mathrm{p}) \\
{ }^{198} \operatorname{Pt}(\mathrm{d}, \mathrm{p} 2 \mathrm{n})\end{array}$ & $\begin{array}{l}3.62 \\
-9.78\end{array}$ \\
\hline $\begin{array}{l}{ }^{188} \mathrm{Ir} \\
1^{-} \\
\varepsilon: 100 \%\end{array}$ & $41.5 \mathrm{~h}$ & $\begin{array}{l}155.05 \\
477.99 \\
633.02\end{array}$ & $\begin{array}{l}30 \\
14.7 \\
18\end{array}$ & $\begin{array}{l}{ }^{190} \operatorname{Pt}(d, 2 p 2 n) \\
{ }^{192} \operatorname{Pt}(d, 2 p 4 n) \\
{ }^{194} \operatorname{Pt}(d, 2 p 6 n)\end{array}$ & $\begin{array}{l}-16.56 \\
-31.67 \\
-46.28\end{array}$ \\
\hline $\begin{array}{l}{ }^{189} \mathrm{Ir} \\
3 / 2^{+} \\
\varepsilon: 100 \%\end{array}$ & $13.2 \mathrm{~d}$ & 245.08 & 6.0 & $\begin{array}{l}{ }^{190} \mathrm{Pt}(\mathrm{d}, 2 \mathrm{pn}) \\
{ }^{192} \mathrm{Pt}(\mathrm{d}, 2 \mathrm{p} 3 \mathrm{n}) \\
{ }^{194} \mathrm{Pt}(\mathrm{d}, 2 \mathrm{p} 5 \mathrm{n}) \\
{ }^{195} \mathrm{Pt}(\mathrm{d}, 2 \mathrm{p} 6 \mathrm{n})\end{array}$ & $\begin{array}{l}-8.38 \\
-23.49 \\
-38.10 \\
-44.21\end{array}$ \\
\hline $\begin{array}{l}{ }_{190 \mathrm{~m}} \mathrm{Ir} \\
(11)^{-} \\
\text {IT: } 8.6 \% \\
\varepsilon: 91.4 \% \\
376.4 \mathrm{keV}\end{array}$ & $3.087 \mathrm{~h}$ & $\begin{array}{l}186.7 \\
361.2 \\
502.5 \\
616.5\end{array}$ & $\begin{array}{l}64.2 \\
86.72 \\
89.38 \\
90.14\end{array}$ & $\begin{array}{l}{ }^{190} \operatorname{Pt}(d, 2 p) \\
{ }^{192} \operatorname{Pt}(d, 2 p 2 n) \\
{ }^{194} \operatorname{Pt}(d, 2 p 4 n) \\
{ }^{195} \operatorname{Pt}(d, 2 p 5 n) \\
{ }^{196} \operatorname{Pt}(d, 2 p 6 n)\end{array}$ & $\begin{array}{l}-2.01 \\
-17.12 \\
-31.73 \\
-37.84 \\
-45.76\end{array}$ \\
\hline $\begin{array}{l}{ }^{190} \mathrm{Ir} \\
4^{-} \\
\varepsilon: 100 \%\end{array}$ & $11.78 \mathrm{~d}$ & $\begin{array}{l}186.68 \\
361.09 \\
371.24 \\
407.22 \\
518.55 \\
557.95 \\
569.30 \\
605.14\end{array}$ & $\begin{array}{l}52 \\
13.0 \\
22.8 \\
28.5 \\
34.0 \\
30.1 \\
28.5 \\
39.9\end{array}$ & $\begin{array}{l}{ }^{190} \mathrm{Pt}(\mathrm{d}, 2 \mathrm{p}) \\
{ }^{192} \mathrm{Pt}(\mathrm{d}, 2 \mathrm{p} 2 \mathrm{n}) \\
{ }^{194} \mathrm{Pt}(\mathrm{d}, 2 \mathrm{p} 4 \mathrm{n}) \\
{ }^{195} \mathrm{Pt}(\mathrm{d}, 2 \mathrm{p} 5 \mathrm{n}) \\
{ }^{196} \mathrm{Pt}(\mathrm{d}, 2 \mathrm{p} 6 \mathrm{n})\end{array}$ & $\begin{array}{l}-2.01 \\
-17.12 \\
-31.73 \\
-37.84 \\
-45.76\end{array}$ \\
\hline $\begin{array}{l}{ }^{192 \mathrm{~g}} \mathrm{Ir} \\
4^{+} \\
\varepsilon: 4.76 \% \\
\beta^{-}: 95.24 \%\end{array}$ & $73.829 \mathrm{~d}$ & $\begin{array}{l}295.95 \\
308.46 \\
316.51 \\
468.07 \\
604.41\end{array}$ & $\begin{array}{l}28.71 \\
29.70 \\
82.86 \\
47.84 \\
8.216\end{array}$ & $\begin{array}{l}{ }^{192} \mathrm{Pt}(\mathrm{d}, 2 \mathrm{p}) \\
{ }^{194} \mathrm{Pt}(\mathrm{d}, 2 \mathrm{p} 2 \mathrm{n}) \\
{ }^{195} \mathrm{Pt}(\mathrm{d}, 2 \mathrm{p} 3 \mathrm{n}) \\
{ }^{196} \mathrm{Pt}(\mathrm{d}, 2 \mathrm{p} 4 \mathrm{n}) \\
{ }^{198} \mathrm{Pt}(\mathrm{d}, 2 \mathrm{p} 6 \mathrm{n})\end{array}$ & $\begin{array}{l}-2.90 \\
-17.51 \\
-23.61 \\
-31.54 \\
-44.94\end{array}$ \\
\hline $\begin{array}{l}{ }^{194 \mathrm{~m} 2} \mathrm{Ir} \\
(10,11) \\
\beta^{-}: 100 \% \\
190.0 \mathrm{keV}\end{array}$ & $171 \mathrm{~d}$ & $\begin{array}{l}328.5 \\
338.8 \\
390.8 \\
482.6 \\
562.4 \\
600.5 \\
687.8\end{array}$ & $\begin{array}{l}93.0 \\
55.0 \\
35.0 \\
97.0 \\
35.0 \\
62.0 \\
59.0\end{array}$ & $\begin{array}{l}{ }^{194} \mathrm{Pt}(\mathrm{d}, 2 \mathrm{p}) \\
{ }_{195} \mathrm{Pt}(\mathrm{d}, 2 \mathrm{pn}) \\
{ }^{196} \mathrm{Pt}(\mathrm{d}, 2 \mathrm{p} 2 \mathrm{n}) \\
{ }^{198} \mathrm{Pt}(\mathrm{d}, 2 \mathrm{p} 4 \mathrm{n})\end{array}$ & $\begin{array}{l}-3.67 \\
-9.78 \\
-17.70 \\
-31.10\end{array}$ \\
\hline
\end{tabular}

bombardment, respectively. Further experimental details are given in our previous work on deuteron induced reactions on manganese [8], which was irradiated in the same stack.

Gamma spectra were evaluated by automatic fitting algorithm included in the Genie 2000 package or in an iterative process using the Forgamma $[9,10]$ code. For data evaluation, NUDAT 2.6 [11] decay data were used (Table 1). As natural platinum consists of several stable isotopes with following abundance (\%): ${ }^{190} \mathrm{Pt}-0.01,{ }^{192} \mathrm{Pt}-0.79,{ }^{194} \mathrm{Pt}-32.9$, ${ }^{195} \mathrm{Pt}-33.8,{ }^{196} \mathrm{Pt}-25.3,{ }^{198} \mathrm{Pt}-7.2$, so called elemental cross sections were deduced.

The $Q$ values of the contributing reactions ( $Q$ value calculator [12]) are also shown in Table 1 to indicate the reaction thresholds. 
Fig. 1 Simultaneously measured experimental data of ${ }^{27} \mathrm{Al}(\mathrm{d}, \mathrm{x})^{22,24} \mathrm{Na}$ monitor reactions in comparison with the recommended values [7]

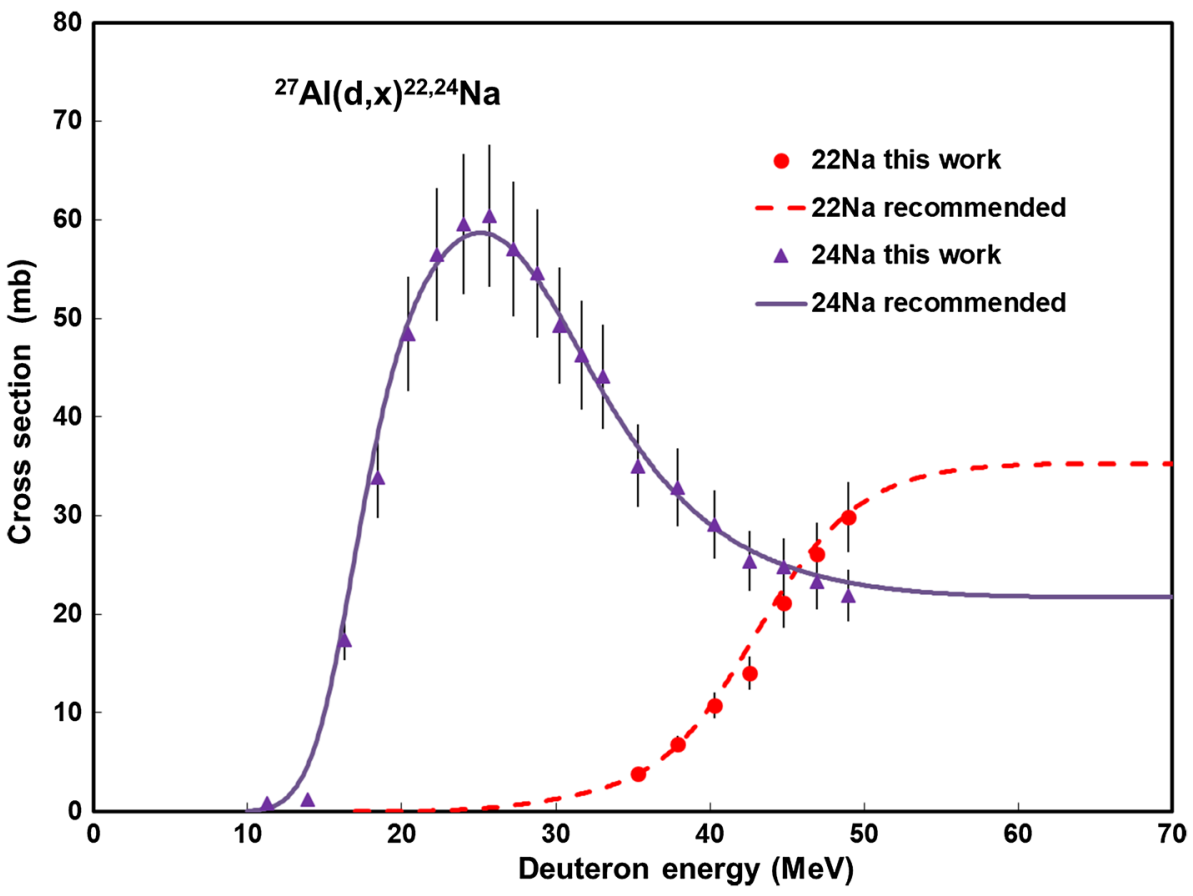

Uncertainty on cross-sections was determined according to the recommendation given in Ref. [13] by taking the sum in quadrature of all individual linear contributions: beam current (7\%), target thickness or homogeneity (5\%), detector efficiency (5\%), photo peak area determination and counting statistics (1-20\%).

The median beam energy in each target foil was obtained by a degradation calculation based on the calibrated primary energy, the stopping powers of Andersen [14] and the fitted monitor reactions (Fig. 1) [15]. Uncertainty of energy was estimated by taking into account cumulative effects during the energy degradation (primary energy, target thickness, energy straggling) and the applied correction to monitor reactions.

Abundance of isotopes of natural Pt $(\%)$ : ${ }^{190} \mathrm{Pt}-0.01$, ${ }^{192} \mathrm{Pt}-0.79,{ }^{194} \mathrm{Pt}-32.9,{ }^{195} \mathrm{Pt}-33.8,{ }^{196} \mathrm{Pt}-25.3,{ }^{198} \mathrm{Pt}-7.2$.

The $Q$-values shown in Table 2 refer to formation of the ground state. Decrease $Q$-values for isomeric states with level energy of the isomer.

When complex particles are emitted instead of individual protons and neutrons the $Q$-values have to be decreased by the respective binding energies of the compound particles: $\mathrm{pn} \rightarrow \mathrm{d}+2.2 \mathrm{MeV}, \mathrm{p} 2 \mathrm{n} \rightarrow \mathrm{t}+8.5 \mathrm{MeV}$, $2 \mathrm{pn} \rightarrow{ }^{3} \mathrm{He}+7.7 \mathrm{MeV}, 2 \mathrm{p} 2 \mathrm{n} \rightarrow \alpha+28.3 \mathrm{MeV}$.

\section{Theoretical calculations}

The cross sections of the investigated reactions were calculated using the pre-compound model codes ALICEIPPE [16] and EMPIRE-II [17] modified for deuterons by
Ignatyuk (D-versions) [18]. These modified codes named ALICE-D and EMPIRE-D were developed by including a simulation of direct $(d, p)$ and $(d, t)$ transitions with the general relations for a nucleon transfer probability in the continuum through an energy dependent enhancement factor for the corresponding transitions. The theoretical curves were determined using one recommended input data-set [19] without any optimization or adjustment of parameters to the individual reactions or stable target isotopes. Independent data for isomers with ALICE-D code were obtained by using the isomeric ratios calculated with EMPIRE-D.

The experimental data are also compared with the cross section data reported in the TENDL-2017 [20] on-line nuclear reaction data library. The TENDL-2017 library is based on both default and adjusted TALYS 1.9 model calculations [21].

We had many problems with these calculations. At the beginning the optical potential for deuterons was taken in accordance with the default RIPL recommendations [22]. As for this potential all Empire results were much higher than he ALICE results, we decided to make new calculations with the Perry potential [23], which we used earlier for the ${ }^{197} \mathrm{Au}$ target [24]. This resulted in certainly more consistency. However, the main problems relate to the levels schemes, which are poor for the most of Pt and Ir isotopes. There are too many low-value spin- and a strong deficit for high-spin levels. So, the calculated isomeric ratios are too low for most cases. In principle some corrections for the spin distributions can be made to get better agreement. 


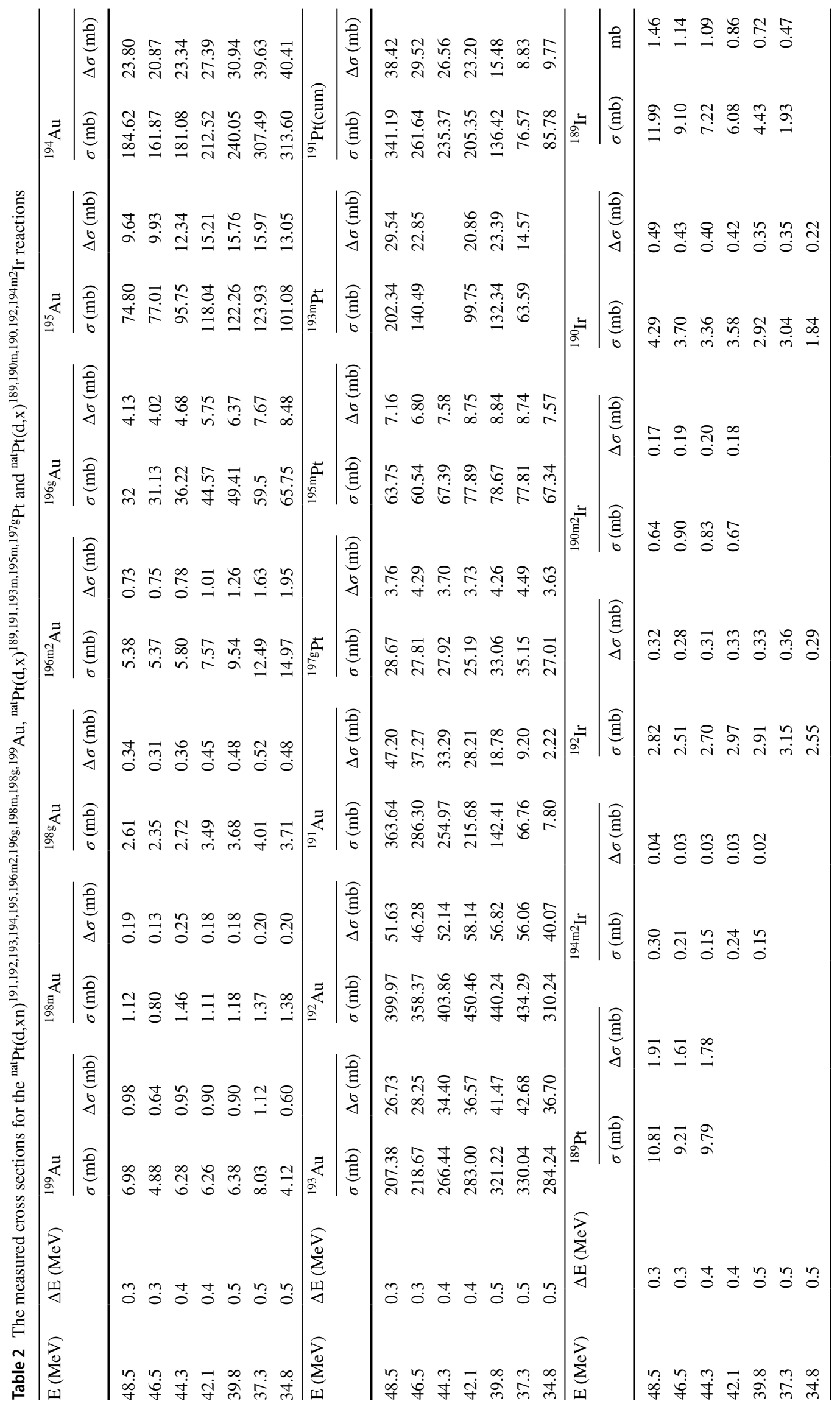


Fig. 2 Excitation function of the ${ }^{\text {nat }} \mathrm{Pt}(\mathrm{d}, \mathrm{x}){ }^{199} \mathrm{Au}(\mathrm{cum})$ reaction in comparison with literature and theoretical values

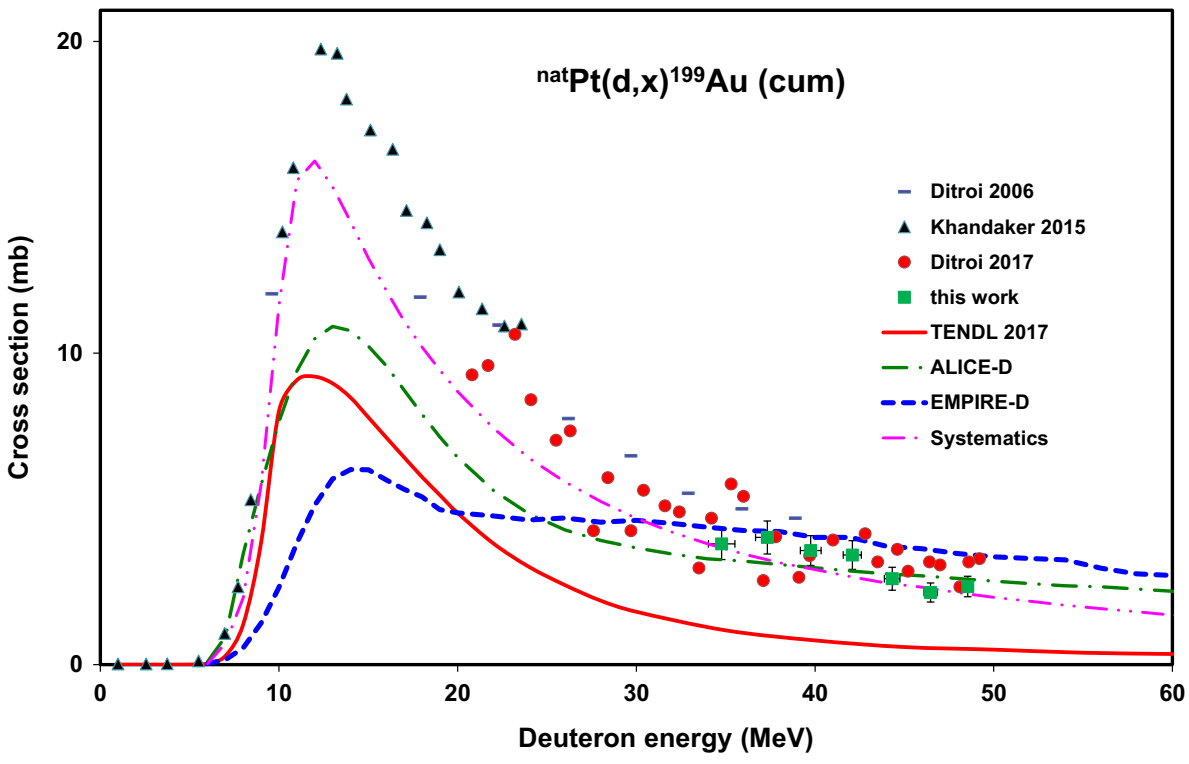

Fig. 3 Excitation function of the ${ }^{\text {nat }} \mathrm{Pt}(\mathrm{d}, \mathrm{x}){ }^{198 \mathrm{~m}} \mathrm{Au}$ reaction in comparison with literature and theoretical values

\section{Results and discussion}

The measured experimental cross-section data are shown in Figs. 2, 3, 4, 5, 6, 7, 8, 9, 10, 11, 12, 13, 14, 15, 16, 17 , $18,19,20,21,22$ and 23 . The numerical values are presented in Table 2. The investigated radio-products can be produced directly, through the internal transition of a longlived isomeric state and through the decay of an isobaric parent. We made theoretical model calculations also for production of a few radioisotopes measured by us earlier, but no new experimental data are presented in this study. Agreement of the available experimental data and the theoretical data can clearly be seen in the figures of the present work. The comparisons result in different conclusions for each reaction, which is hard to explain. Some more detailed discussions are available in our previous work [6]. Therefore, in the summary we present only general conclusion on the predictive capability of the model calculations.

\section{Radioisotopes of gold}

${ }^{n a t} P t(d, x){ }^{199} A u(c u m)$ reaction The measured cross-sections of the ${ }^{199} \mathrm{Au}\left(T_{1 / 2}=3.139 \mathrm{~d}\right)$ are cumulative, produced directly through the ${ }^{198} \mathrm{Pt}(\mathrm{d}, \mathrm{n})$ reaction and contribution of the $\beta^{-}$-decay of the shorter-lived parent ${ }^{199} \mathrm{Pt}$ $\left(T_{1 / 2}=30.8 \mathrm{~min}\right)$ produced through the ${ }^{198} \mathrm{Pt}(\mathrm{d}, \mathrm{p})$ process 
Fig. 4 Excitation function of the ${ }^{\text {nat }} \operatorname{Pt}(\mathrm{d}, \mathrm{xn}){ }^{198 \mathrm{~g}} \mathrm{Au}$ reaction in comparison with literature and theoretical values
Fig. 5 Excitation function of the ${ }^{\text {nat }} \mathrm{Pt}(\mathrm{d}, \mathrm{xn}){ }^{196 \mathrm{~m} 2} \mathrm{Au}$ reaction in comparison with literature and theoretical values
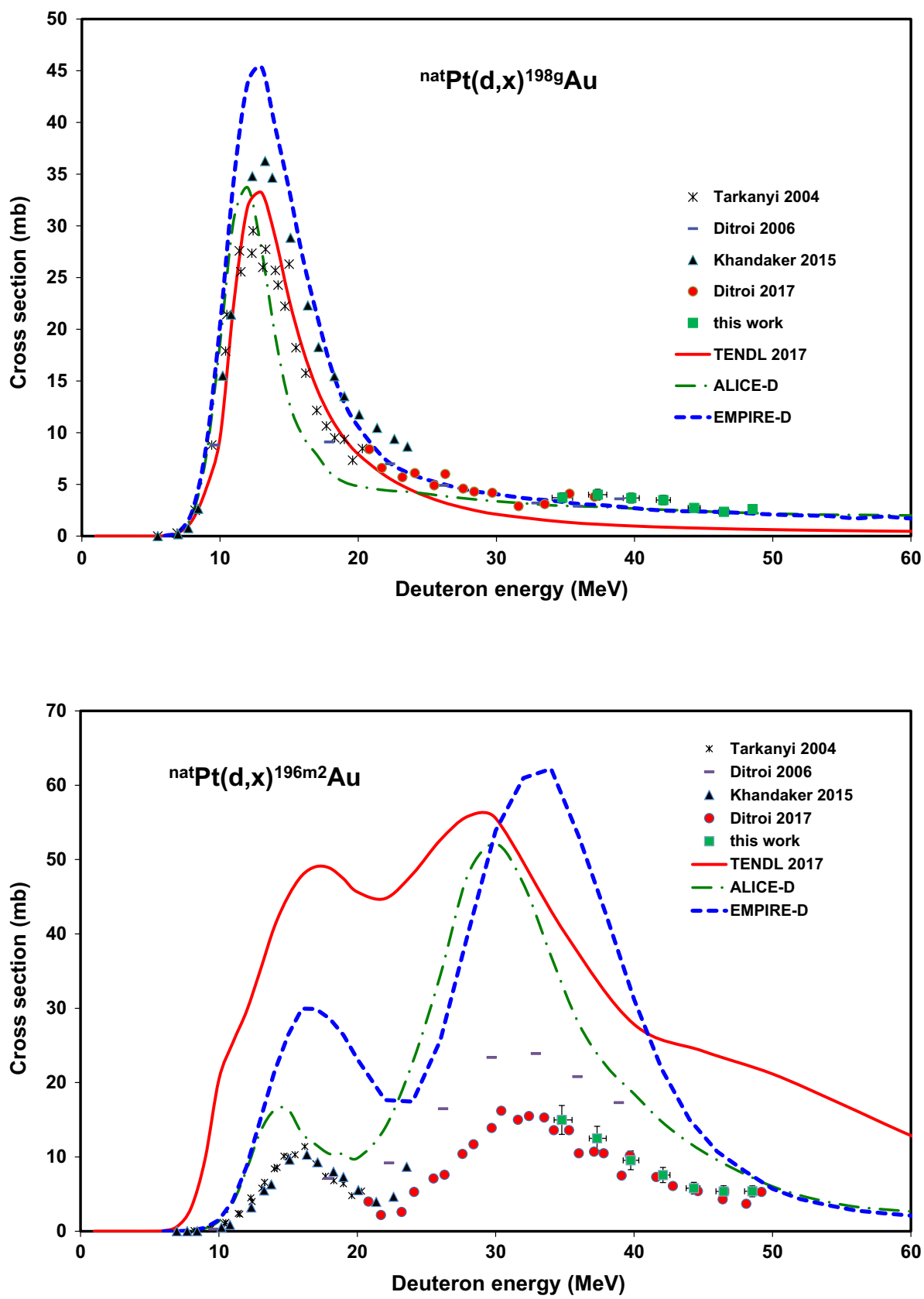

(Fig. 2). A good agreement with the earlier experimental studies $[6,7]$ in the overlapping energy interval is seen. Because none of the theoretical model code gave acceptable predictions for the experimental values an estimated prediction from the systematics has also be presented in Fig. 2, which is proved to be the best approximation both in trend and in values.

${ }^{\text {nat }} \operatorname{Pt}(d, x)^{198 m}$ Au reaction We could obtain cross section data for both longer-lived states of ${ }^{198} \mathrm{Au}$. The cross sections for the ${ }^{198 \mathrm{~m}} \mathrm{Au}\left(T_{1 / 2}=2.272 \mathrm{~d}\right.$, IT $\left.100 \%\right)$ isomeric state are shown in Fig. 3. An acceptable continuation to higher energy of the data of Ditroi et al. [4] is seen. All the three model codes predict a large peak around 16-17 MeV, which was not confirmed by any of the experiments.

${ }^{n a t} \operatorname{Pt}(d, x n){ }^{198 g} A u$ reaction Independent, low, cross sections for direct production of the ground state of ${ }^{198} \mathrm{Au}$ $\left(T_{1 / 2}=2.6947 \mathrm{~d}\right)$ are shown in Fig. 4 and are in acceptable agreement with the earlier values. The trends given by all model codes are good. The best value is estimated by the EMPIRE-D above $20 \mathrm{MeV}$, but it overestiimates strongly around the maximum. 
Fig. 6 Excitation function of the ${ }^{\text {nat }} \mathrm{Pt}(\mathrm{d}, \mathrm{xn}){ }^{196 \mathrm{~g}} \mathrm{Au}$ (cum) reaction in comparison with literature and theoretical values

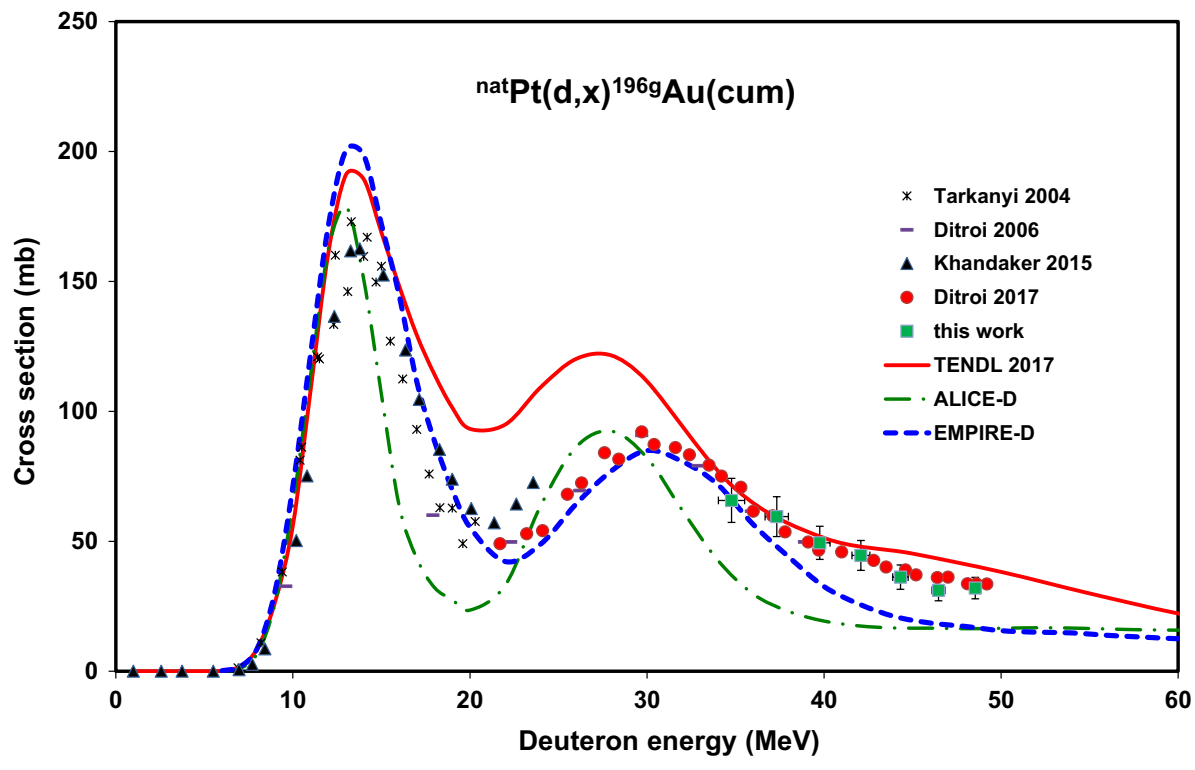

Fig. 7 Excitation function of the ${ }^{\text {nat }} \operatorname{Pt}(\mathrm{d}, \mathrm{xn}){ }^{195} \mathrm{Au}(\mathrm{cum})$ reaction in comparison with literature and theoretical values

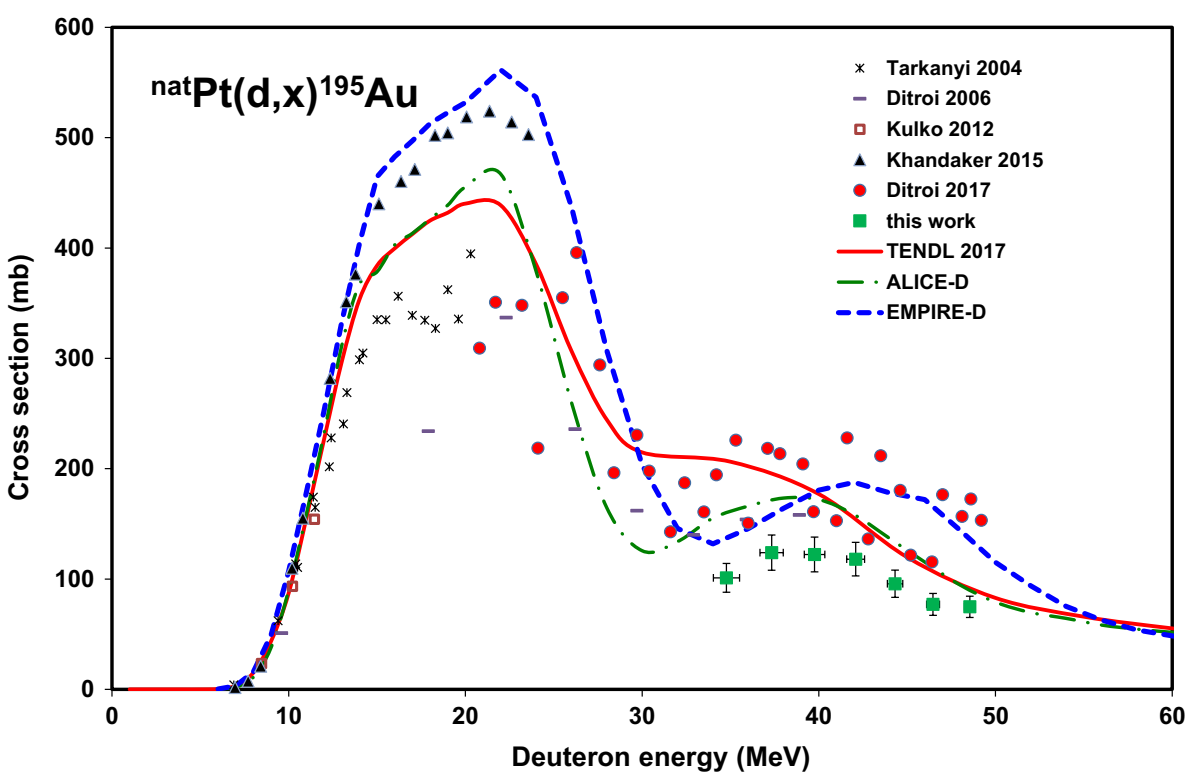

${ }^{n a t} P t(d, x n){ }^{196 m 2}$ Au reaction Direct production cross-sections for the $T_{1 / 2}=9.6 \mathrm{~h}$ isomeric state ${ }^{196 \mathrm{~m} 2} \mathrm{Au}$ are shown in Fig. 5 and agree well with the Ditroi et al. [6] data. All theoretical model codes recognize the two maxima, but all overestimate the experimental values.

${ }^{\text {nat }} \operatorname{Pt}(d, x n){ }^{196 g} A u(c u m)$ reaction The cross sections for cumulative formation of the ground state ${ }^{196 \mathrm{~g}} \mathrm{Au}\left(T_{1 / 2}=6.1669 \mathrm{~d}\right)$ measured after the complete decay of the two higher laying, short-lived, isomeric states $\left(\mathrm{m} 2-T_{1 / 2}=9.6 \mathrm{~h}, \mathrm{~m} 1-T_{1 / 2}=8.1 \mathrm{~s}\right)$ are shown in Fig. 6. Very good agreement with Ditroi et al. [6] was observed. All model codes describe the shape of the excitation function almost correctly, the best value approximation is given by the EMPIRE-D code.

${ }^{\text {nat }} \operatorname{Pt}(d, x n){ }^{195} \mathrm{Au}$ (cum) reaction The cross-sections for formation of ${ }^{195} \mathrm{Au}\left(T_{1 / 2}=186.01 \mathrm{~d}\right)$ contain the decay of the $T_{1 / 2}=30.5 \mathrm{~s}$ isomeric state (Fig. 7) and are lower than the rather scattered data of Ditroi et al. [6]. The theoretical codes follow the trend of the experimental curves, but give different value predictions.

${ }^{n a t} \operatorname{Pt}(d, x n){ }^{194} A u$ reaction The excitation functions for production of the directly produced ${ }^{194} \mathrm{Au}\left(T_{1 / 2}=38.02 \mathrm{~h}\right)$ are 
Fig. 8 Excitation function of the ${ }^{\text {nat }} \mathrm{Pt}(\mathrm{d}, \mathrm{xn}){ }^{194} \mathrm{Au}$ reaction in comparison with literature and theoretical values
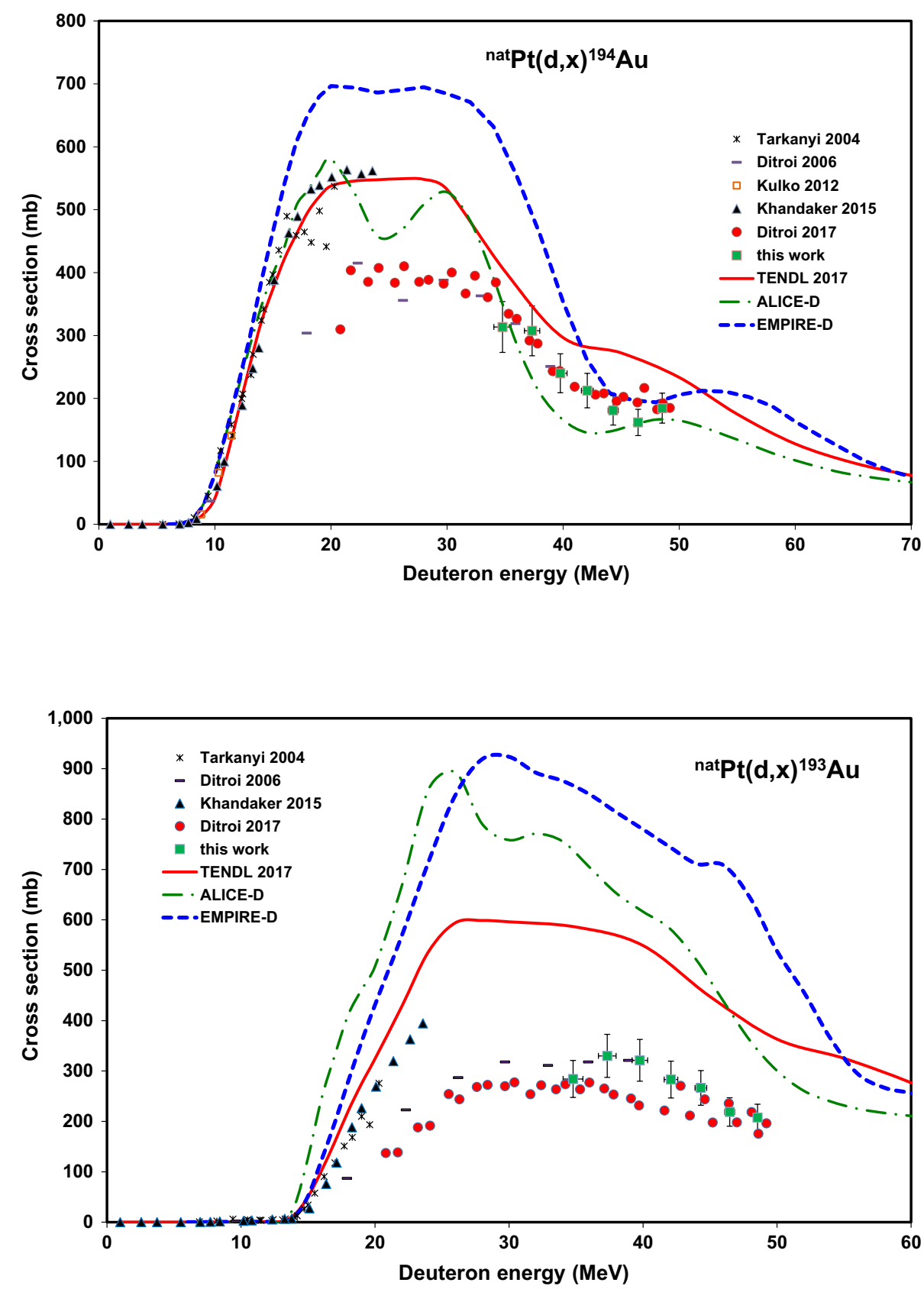

Fig. 9 Excitation function of the ${ }^{n a t} \mathrm{Pt}(\mathrm{d}, \mathrm{xn}){ }^{193} \mathrm{Au}(\mathrm{cum})$ reaction in comparison with literature and theoretical values shown in Fig. 8 and are in perfect agreement with Ditroi et al. [6]. The theoretical model codes give different values around the maxima, their approximation is acceptable only below $20 \mathrm{MeV}$.

${ }^{\text {nat }} \operatorname{Pt}(d, x n){ }^{193 g} A u(c u m)$ reaction The measured cross-sections of ${ }^{193 \mathrm{~g}} \mathrm{Au}\left(T_{1 / 2}=17.65 \mathrm{~h}\right)$ include the internal decay of the $T_{1 / 2}=3.9 \mathrm{~s}$ isomeric state (Fig. 9) additional to the direct production. The new measurements are about $20 \%$ higher than a part of the values in Ditroi et al. [6] but seem to agree better with the 2006 values [4]. All the theoretical model codes strongly overestimate the experimental values.

${ }^{n a t} P t(d, x n){ }^{192} A u$ reaction The activation cross sections for production of ${ }^{192} \mathrm{Au}\left(T_{1 / 2}=4.94 \mathrm{~h}\right)$ are shown in Fig. 10 and are between our earlier values given in Refs. [4] and [6]. The best prediction is given by the TENDL-2017, both other model codes strongly overestimate the experimental values. 
Fig. 10 Excitation function of the ${ }^{\text {nat }} \mathrm{Pt}(\mathrm{d}, \mathrm{xn}){ }^{192} \mathrm{Au}$ reaction

Fig. 11 Excitation function of the ${ }^{\text {nat }} \operatorname{Pt}(\mathrm{d}, \mathrm{xn}){ }^{191} \mathrm{Au}$ reaction in comparison with literature and theoretical values
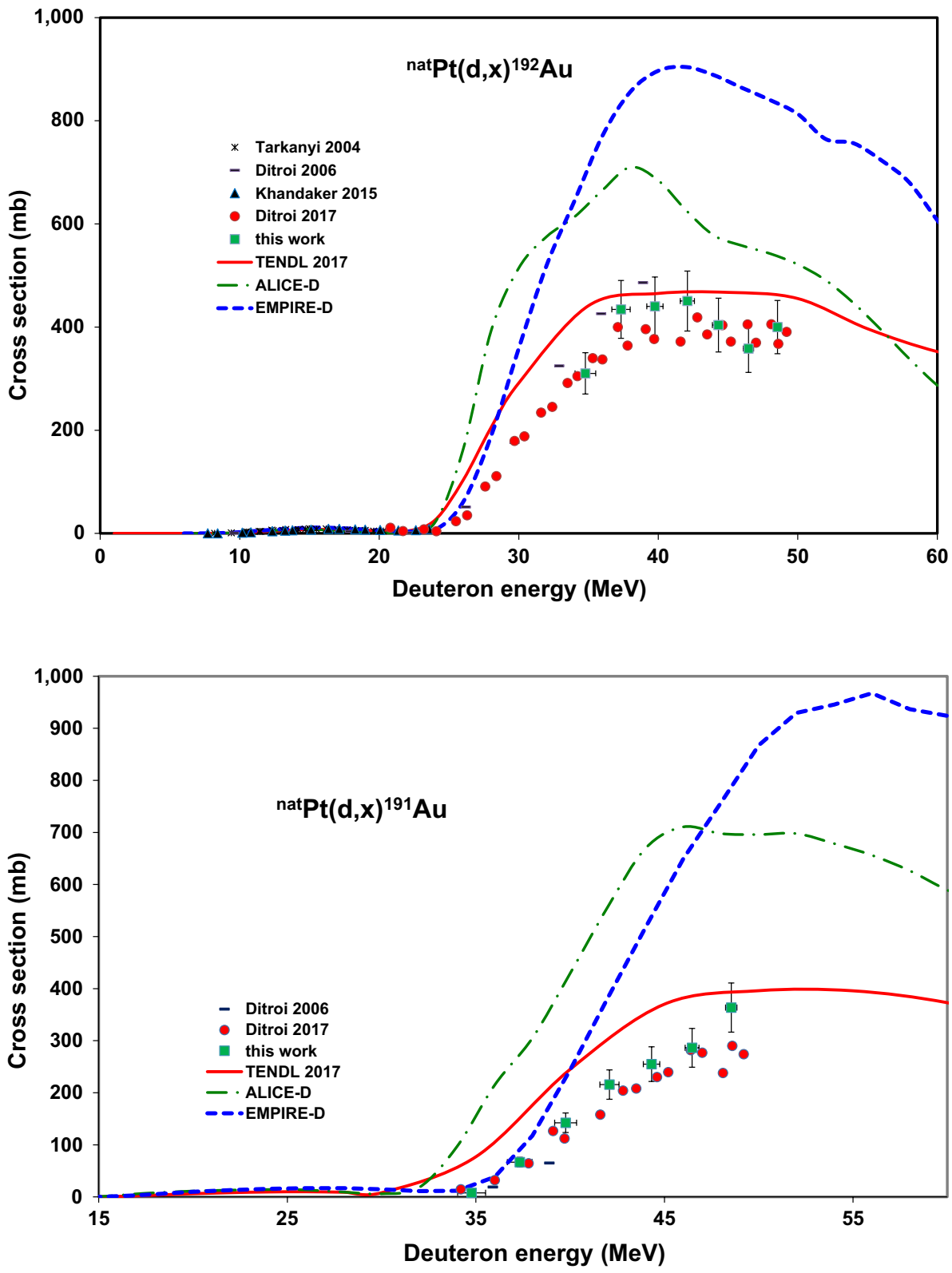

${ }^{n a t} P t(d, x n){ }^{191}$ Au reaction The cross section data of ${ }^{191} \mathrm{Au}$ $\left(T_{1 / 2}=3.18 \mathrm{~h}\right)$ include the contribution from the decay of the simultaneously produced short half-life isomeric state $\left(T_{1 / 2}=0.92 \mathrm{~s}, 100 \%\right.$ IT) (Fig. 11). Good overall agreement with Ditroi et al. [6]. Only TENDL-2017 follows correctly the trend of the experimental values with considerable overestimation.

\section{Radioisotopes of platinum}

${ }^{n a t} P t(d, x){ }^{197 m}$ Pt reaction We could not deduce cross section data for production of the ${ }^{197 \mathrm{~m}} \mathrm{Pt}\left(T_{1 / 2}=95.41 \mathrm{~min}\right)$, due to the long cooling time before measuring the first spectra. The earlier experimental data and the theoretical predictions are shown in Fig. 12. In spite of the large experimental uncertainties the best approximation is given by the TENDL-2017.

${ }^{n a t} P t(d, x){ }^{1979} P t(m+)$ (cum) reaction The measured production cross-section of ${ }^{197 \mathrm{~g}} \mathrm{Pt}\left(T_{1 / 2}=19.8915 \mathrm{~h}\right)$ is including the direct production, the contribution from internal transition ( $T_{1 / 2}=95.41 \mathrm{~min}$, IT: 96.7$)$ of the isomeric state and from the $\beta^{-}$decay of the short-lived ${ }^{197 \mathrm{~m}, \mathrm{~g}} \mathrm{Ir}$ isomers $\left(T_{1 / 2}=5.8 \mathrm{~min}\right.$ and $8.9 \mathrm{~min}$, respectively) (Fig. 13). Our new measurements are in better agreement with the Ditroi et al. [4] values than with the results in Ditroi et al. [6]. All the three theoretical model codes show the trend of the 
Fig. 12 Excitation function of the ${ }^{\text {nat }} \operatorname{Pt}(\mathrm{d}, \mathrm{xn})^{197 \mathrm{~m}} \mathrm{Pt}$ reaction in comparison with theoretical values

Fig. 13 Excitation function of the ${ }^{\text {nat }} \operatorname{Pt}(\mathrm{d}, \mathrm{x}){ }^{197 \mathrm{~g}} \operatorname{Pt}(\mathrm{m}+)(\mathrm{cum})$ reaction in comparison with literature and theoretical values
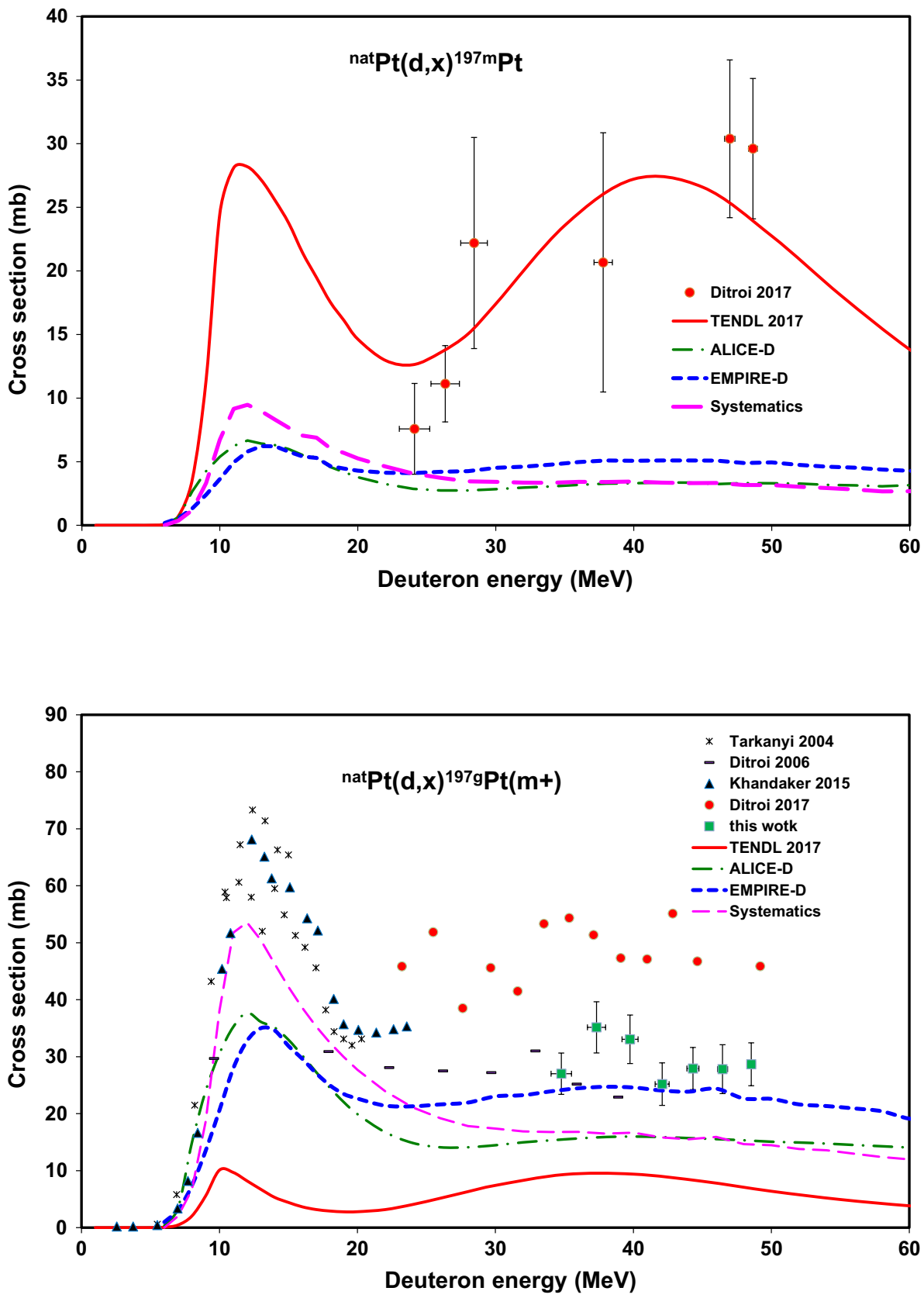

experimental values, but strongly underestimate them. Only the prediction of EMPIRE-D is closed to the experimental results above $25 \mathrm{MeV}$. Even the systematics cannot reconstruct the experimental results.

${ }^{n a t} P t(d, x)^{195 m} P$ treaction The excitation function of the high spin isomeric state $\left(T_{1 / 2}=4.02 \mathrm{~d}\right)$ of ${ }^{195} \mathrm{Pt}$ is shown in Fig. 14 and confirm overall the previously measured values of [4] and [6]. All theoretical predictions follow the trend of the experimental values, but TENDL strongly overestimates, while ALICE-D and EMPIRE-D giving approximately the same underestimated values.

${ }^{n a t} P t(d, x)^{193 m} P$ t reaction The cross sections for production of ${ }^{193 \mathrm{~m}} \mathrm{Pt}\left(T_{1 / 2}=4.33 \mathrm{~d}\right.$, IT: $\left.100 \%\right)$ are shown in Fig. 15. They include the contribution of $0.03 \%$ EC decay of ${ }^{193 \mathrm{~m}} \mathrm{Au}$ ( $\left.T_{1 / 2}=3,9 \mathrm{~s}\right)$. No earlier experimental data were found. Only the TENDL-2017 prediction gives an acceptable trend but with slight overestimation. 
Fig. 14 Excitation function of the ${ }^{\text {nat }} \mathrm{Pt}(\mathrm{d}, \mathrm{xn}){ }^{195 \mathrm{~m}} \mathrm{Pt}$ reaction in comparison with literature and theoretical values

Fig. 15 Excitation function of the ${ }^{\text {nat }} \mathrm{Pt}(\mathrm{d}, \mathrm{xn}){ }^{193 \mathrm{~m}} \mathrm{Pt}$ reaction in comparison with theoretical values
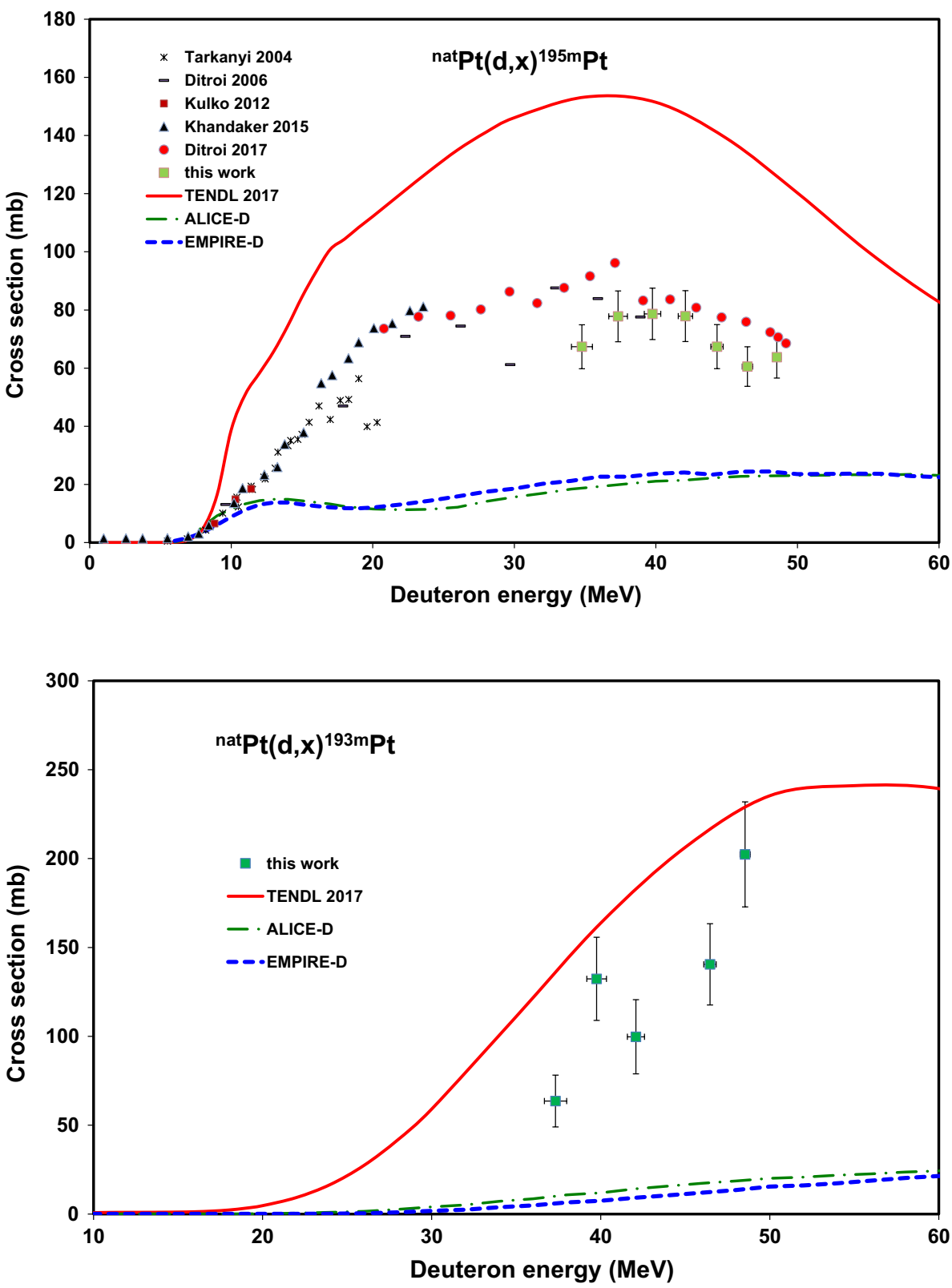

${ }^{\text {nat }} \mathrm{Pt}(\mathrm{d}, \mathrm{x}){ }^{191} \mathrm{Pt}$ (cum) reaction The cumulative cross-sections for production of ${ }^{191} \mathrm{Pt}\left(T_{1 / 2}=2.802 \mathrm{~d}\right)$ includes direct production and formation through decay of ${ }^{191} \mathrm{Au}\left(T_{1 / 2}=3.18 \mathrm{~h}\right)$ and is shown in Fig. 16. Above $40 \mathrm{MeV}$ the new values are significantly lower than the Ditroi et al. [6] data. The three theoretical model calculations give different results, the best approximation is given by the EMPIRE-D up to $40 \mathrm{MeV}$, but above this energy the TENDL-2017 predictions are better.

${ }^{\text {nat }} \mathrm{Pt}(\mathrm{d}, \mathrm{x})^{189} \mathrm{Pt}$ (cum) reaction The cross-sections for production of ${ }^{189} \mathrm{Pt}\left(T_{1 / 2}=11 \mathrm{~h}\right)$ are cumulative, measured after the complete decay of the two longer-lived states of the parent
${ }^{189} \mathrm{Au}\left(T_{1 / 2}=4.6 \mathrm{~min}\right.$ and $\left.28.3 \mathrm{~min}\right)$ radioisotope (Fig. 17). Good agreement of the few data points with the earlier measurement [6] was found. In this energy range all the three theoretical codes give acceptable predictions.

${ }^{n a t} P t(d, x){ }^{188} P t($ cum $)$ reaction Only a single cross section point for formation of ${ }^{188} \mathrm{Pt}\left(T_{1 / 2}=10.2 \mathrm{~d}\right)$ is available, reported in earlier work [6] (Fig. 18). The cross-section contains the contribution of the direct production and the simultaneous decay of the ${ }^{188} \mathrm{Au}\left(T_{1 / 2}=8.8 \mathrm{~min}\right)$ parent. The theoretical model codes give very different predictions. 
Fig. 16 Excitation function of the ${ }^{\text {nat }} \mathrm{Pt}(\mathrm{d}, \mathrm{xn})^{191} \mathrm{Pt}$ reaction in comparison with literature and theoretical values

Fig. 17 Excitation function of the ${ }^{\text {nat }} \mathrm{Pt}(\mathrm{d}, \mathrm{xn})^{189} \mathrm{Pt}$ reaction in comparison with literature and theoretical values
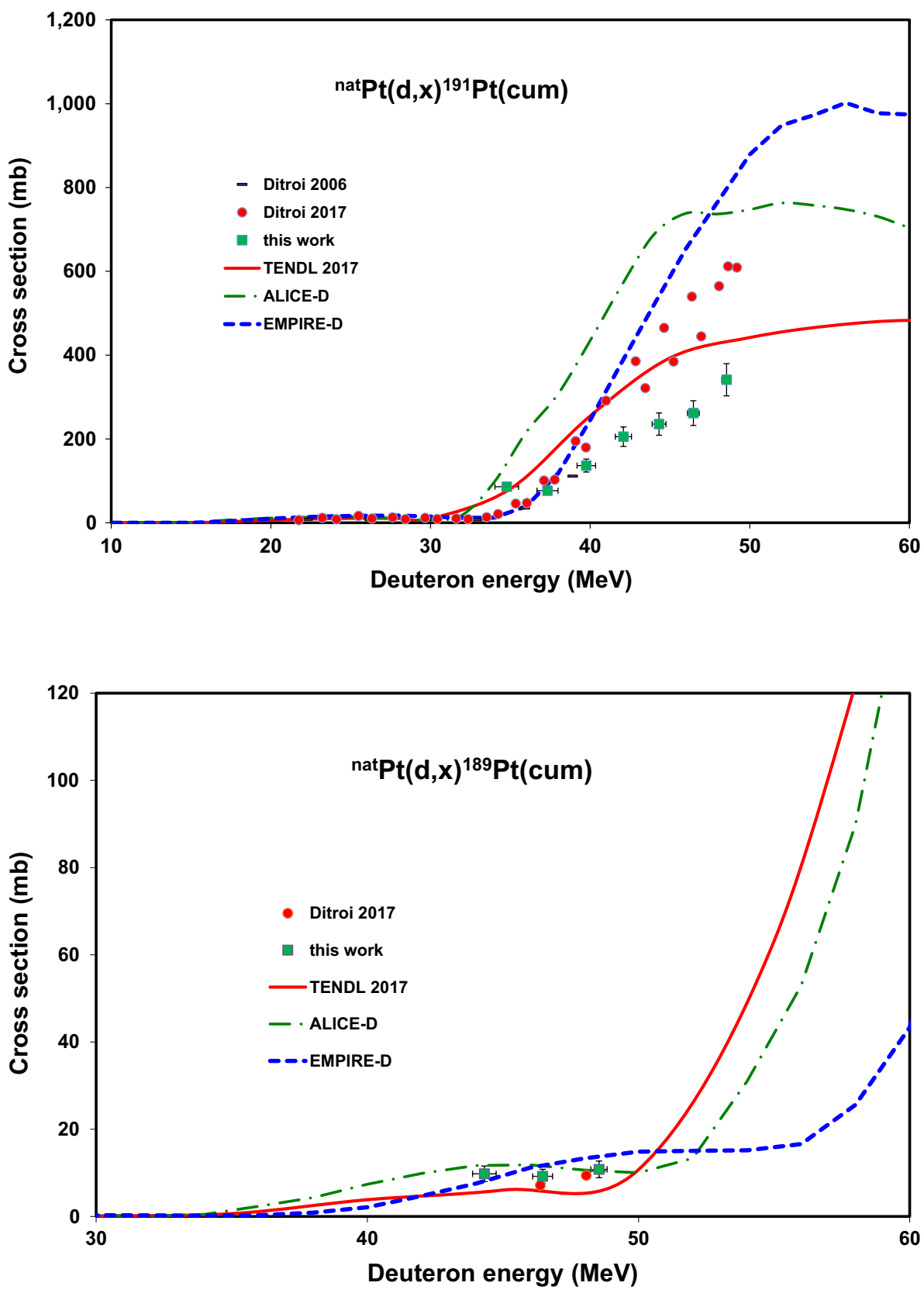

\section{Radioisotopes of iridium}

${ }^{\text {nat }} \operatorname{Pt}(d, x)^{194 m 2}$ Ir reaction The measured spectra allow to get cross sections only for the second, long-lived $\left(T_{1 / 2}=171\right.$ d) metastable state (Fig. 19) out of the three longer-lived states of ${ }^{194} \mathrm{Ir}$. Overall agreement between the new values and Ditroi et al. [6] was seen. TENDL-2017 and ALICE-D give similar trends, but with over- and underestimation. The EMPIRE-D prediction is much lower.

${ }^{\text {nat }} P t(d, x)^{192} \operatorname{Ir}($ cum $)$ reaction Our experimental data (Fig. 20) include the direct production of the ground state $\left(T_{1 / 2}=3.8\right.$ d) and the decay of the short-lived isomeric state ${ }^{192 \mathrm{~m} 1} \mathrm{Ir}$
$\left(T_{1 / 2}=1.45 \mathrm{~min}\right)$. Overall agreement between the new values and Ditroi et al. [6] was seen. ALICE-D gives good approximation of the measured values in the whole energy region, while EMPIRE-D slightly overestimates. TENDL2017 gives strong underestimated prediction.

${ }^{n a t} P t(d, x)^{190 m 2}$ Ir reaction The production cross sections of the second, high spin isomeric state ${ }^{190 \mathrm{~m} 2} \operatorname{Ir}\left(T_{1 / 2}=3.25 \mathrm{~h}\right)$ are shown in Fig. 21 and agree well with the TENDL-2017 prediction while the values of the other codes are 4-10 times too high. No earlier experimental data are available in the literature. 
Fig. 18 Excitation function of the ${ }^{\text {nat }} \mathrm{Pt}(\mathrm{d}, \mathrm{xn}){ }^{188} \mathrm{Pt}$ reaction in comparison with theoretical values

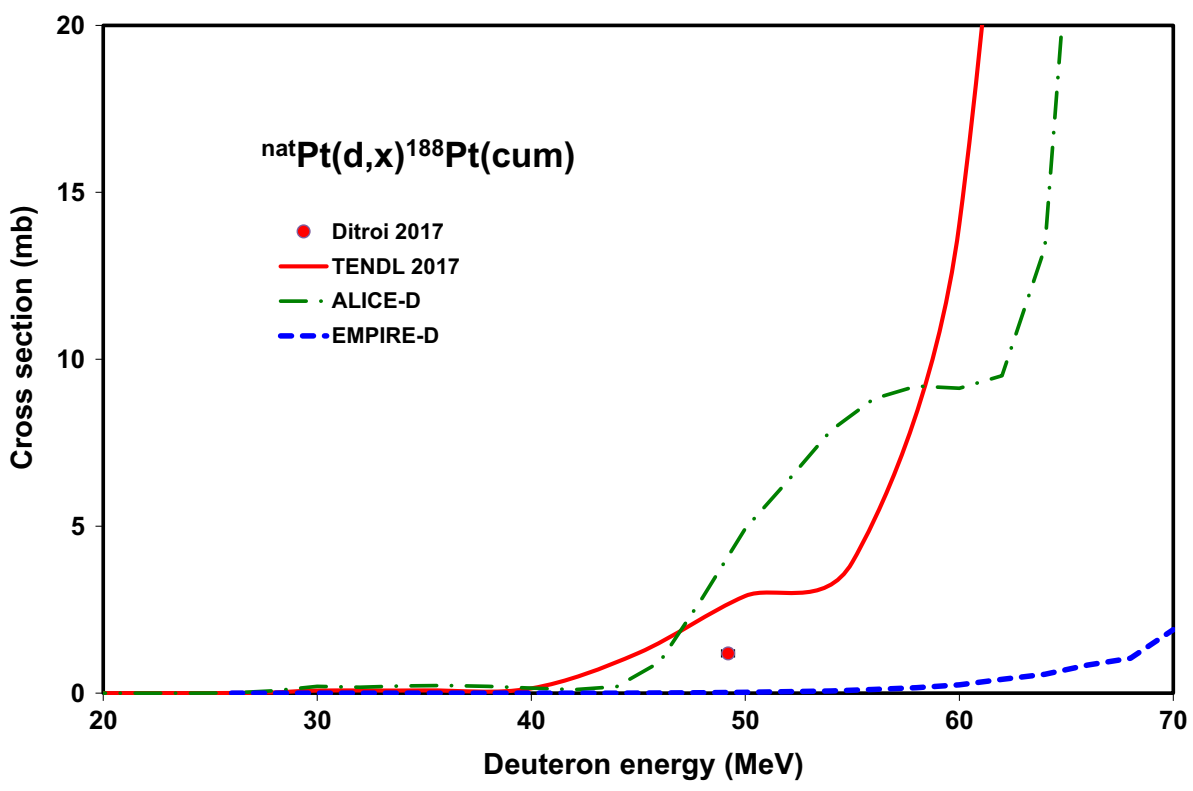

Fig. 19 Excitation function of the ${ }^{\text {nat }} \operatorname{Pt}(\mathrm{d}, \mathrm{xn}){ }^{194 \mathrm{~m} 2}$ Ir reaction in comparison with literature and theoretical values

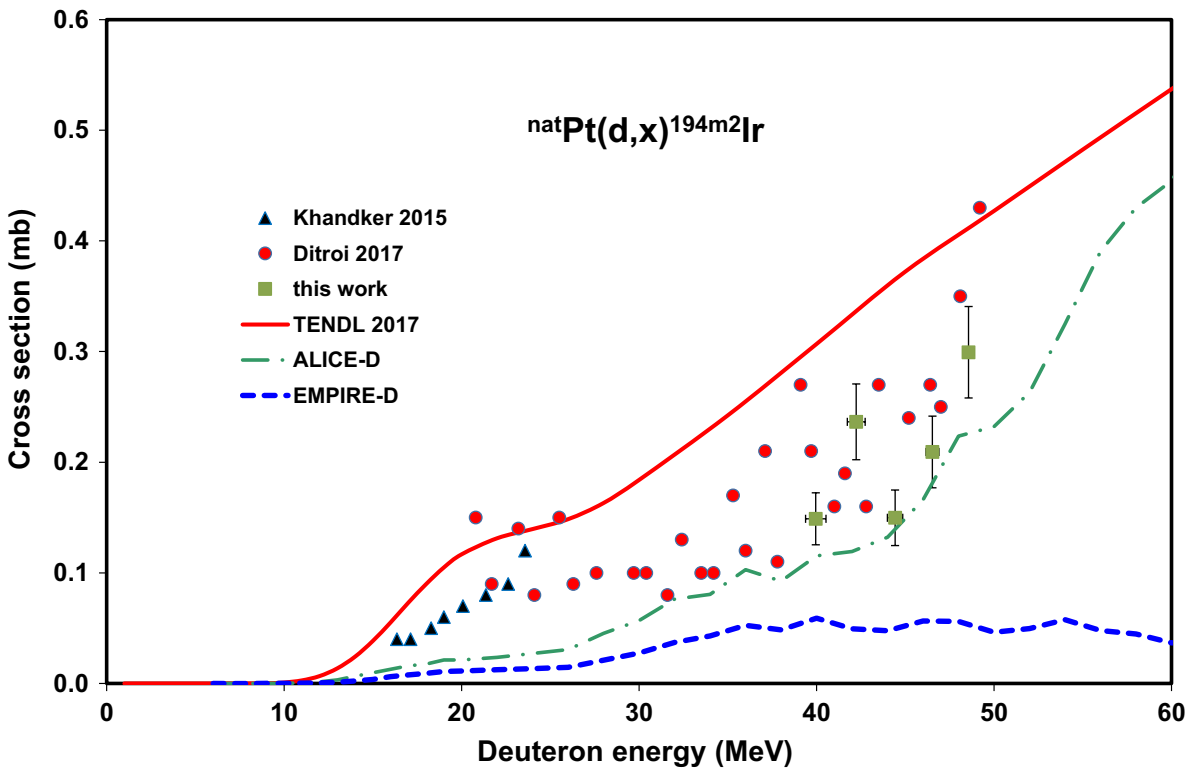

${ }^{\text {nat }} \operatorname{Pt}(d, x)^{190} \operatorname{Ir}(m+)$ reaction The measured cross sections of the ground state $\left(T_{1 / 2}=11.8 \mathrm{~d}\right)$ include, in addition to the direct production, the decay of the first metastable state ${ }^{190 \mathrm{~m} 1} \operatorname{Ir}\left(T_{1 / 2}=1.2 \mathrm{~h}\right.$, IT $\left.100 \%\right)$ and the second high-spin isomeric state ${ }^{190 \mathrm{~m} 2} \operatorname{Ir}\left(T_{1 / 2}=3.25 \mathrm{~h}\right.$, IT 5.6\%) (Fig. 22). Our new values are about $10 \%$ lower than Ditroi et al. [6]. TENDL2017 underestimates, while EMPIRE-D and ALICE-D overestimate the experimental values.

${ }^{n a t} \operatorname{Pt}(d, x)^{189} \operatorname{Ir}($ cum $)$ reaction The cross-section determined for ${ }^{189} \operatorname{Ir}\left(T_{1 / 2}=13.2 \mathrm{~d}\right)$ is cumulative and contains the direct production and the contribution from the decay of ${ }^{189} \mathrm{Pt}$
$\left(T_{1 / 2}=10.87 \mathrm{~h}\right)$ (Fig. 23). Perfect agreement with Ditroi et al. [6] was found. In this energy region the TENDL-2017 prediction is acceptable, while the ALICE-D and EMPIRE-D results overestimate the experimental values.

${ }^{\text {nat }} \operatorname{Pt}(d, x)^{188} \operatorname{Ir}($ cum $)$ reaction The cross-section determined for ${ }^{188} \operatorname{Ir}\left(T_{1 / 2}=41.5 \mathrm{~h}\right)$ is cumulative and contains the direct production and the contribution from the decay of ${ }^{188} \mathrm{Pt}$ $\left(T_{1 / 2}=10.2 \mathrm{~d}\right)$ (Fig. 24). In this energy region the TENDL2017 prediction is acceptable with slight overestimation, while the ALICE-D and EMPIRE-D results overestimate the experimental values. 
Fig. 20 Excitation function of the ${ }^{\text {nat }} \operatorname{Pt}(\mathrm{d}, \mathrm{xn}){ }^{192} \mathrm{Ir}$ reaction in comparison with literature and theoretical values

Fig. 21 Excitation function of the ${ }^{\text {nat }} \operatorname{Pt}(\mathrm{d}, \mathrm{xn})^{190 \mathrm{~m} 2}$ Ir reaction in comparison with theoretical values
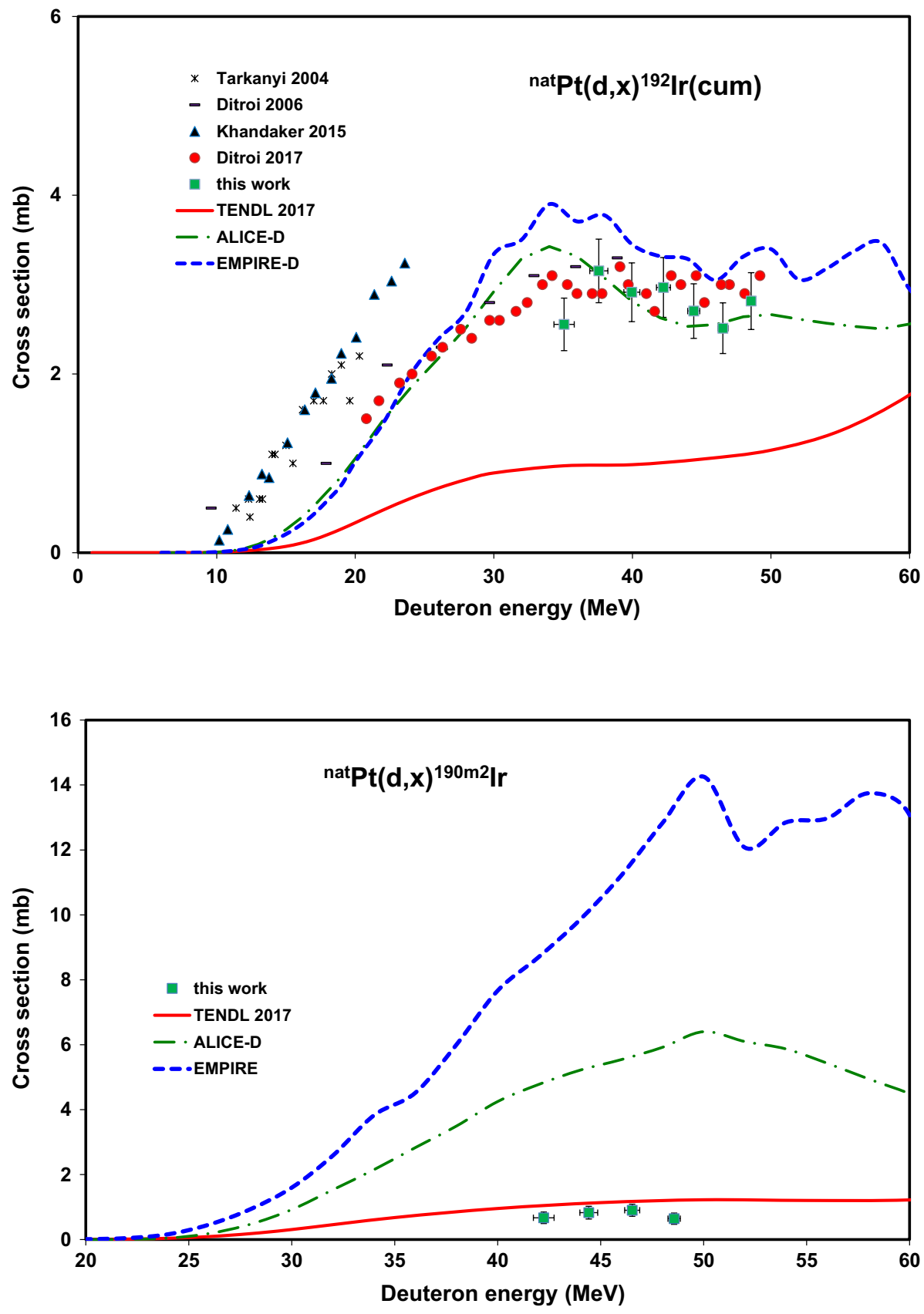

\section{Summary and conclusion}

We report on new experimental cross sections leading to formation of ${ }^{\text {nat }} \mathrm{Pt}(\mathrm{d}, \mathrm{xn}){ }^{191,192,193,194,195,196 \mathrm{~m} 2,196 \mathrm{~g}, 198 \mathrm{~m}, 198 \mathrm{~g}, 199} \mathrm{Au}$, ${ }^{n a t} \operatorname{Pt}(\mathrm{d}, \mathrm{x}){ }^{189,191,193 \mathrm{~m}, 195 \mathrm{~m}, 197 \mathrm{~g} P t}$ and ${ }^{\mathrm{nat}} \mathrm{Pt}(\mathrm{d}, \mathrm{x}$ )$^{188,189,190 \mathrm{~m} 2,190,192,194 \mathrm{~m} 2} \mathrm{Ir}$ in the 35-49 MeV energy range. For production of ${ }^{193 \mathrm{~m}} \mathrm{Pt}$ and ${ }^{188,190 \mathrm{~m}} \mathrm{Ir}$ no earlier experimental data were found. A partial or good agreement was found with the results of our previous studies in the overlapping energy regions, but some cases there are large disagreements. The comparison with the theoretical predictions of TENDL-2017 shows moderate agreement or large disagreement especially for isomeric cross sections. The situation is nearly same in the case of ALICE-D and EMPIRE-D, which underline the importance of experimental data that can help to still improve the codes and models, especially for deuteron induced reactions. 
Fig. 22 Excitation function of the ${ }^{\text {nat }} \mathrm{Pt}(\mathrm{d}, \mathrm{xn}){ }^{190}$ Ir reaction in comparison with literature and theoretical values

Fig. 23 Excitation function of the ${ }^{\text {nat }} \operatorname{Pt}(\mathrm{d}, \mathrm{xn}){ }^{189}$ Ir reaction in comparison with literature and theoretical values
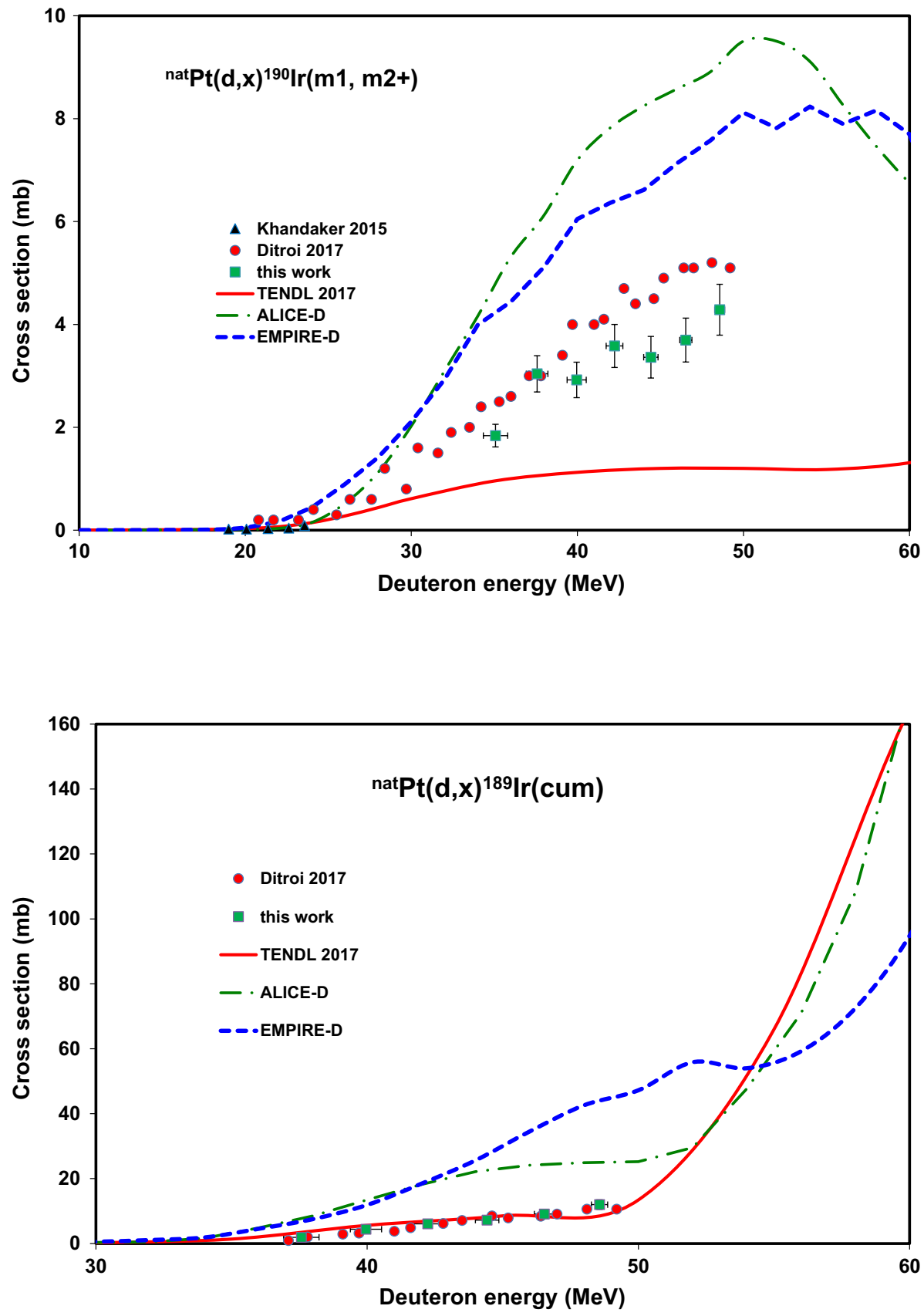

The EMPIRE and TALYS are more recent and advanced codes comparing to ALICE. In practical applications the TALYS based TENDL library is most widely used due to availability of the calculated data in the web. In case of all codes there are significant problems for deuteron induced reactions. Therefore, detailed improvement in the model codes are under development in a few laboratories. The
ALICE-D and Empire-D are one way of improvement by using correction, based on systematics.

Knowing the results and adjusting the used parameters a better agreement can be reached. The aim of our calculation and comparison was to show the predictivity by standard parameters, illustrating reliability of the model codes in case of unmeasured excitation functions. 
Fig. 24 Excitation function of the ${ }^{\text {nat }} \operatorname{Pt}(\mathrm{d}, \mathrm{xn})^{188} \mathrm{Ir}$ reaction in comparison with literature and theoretical values

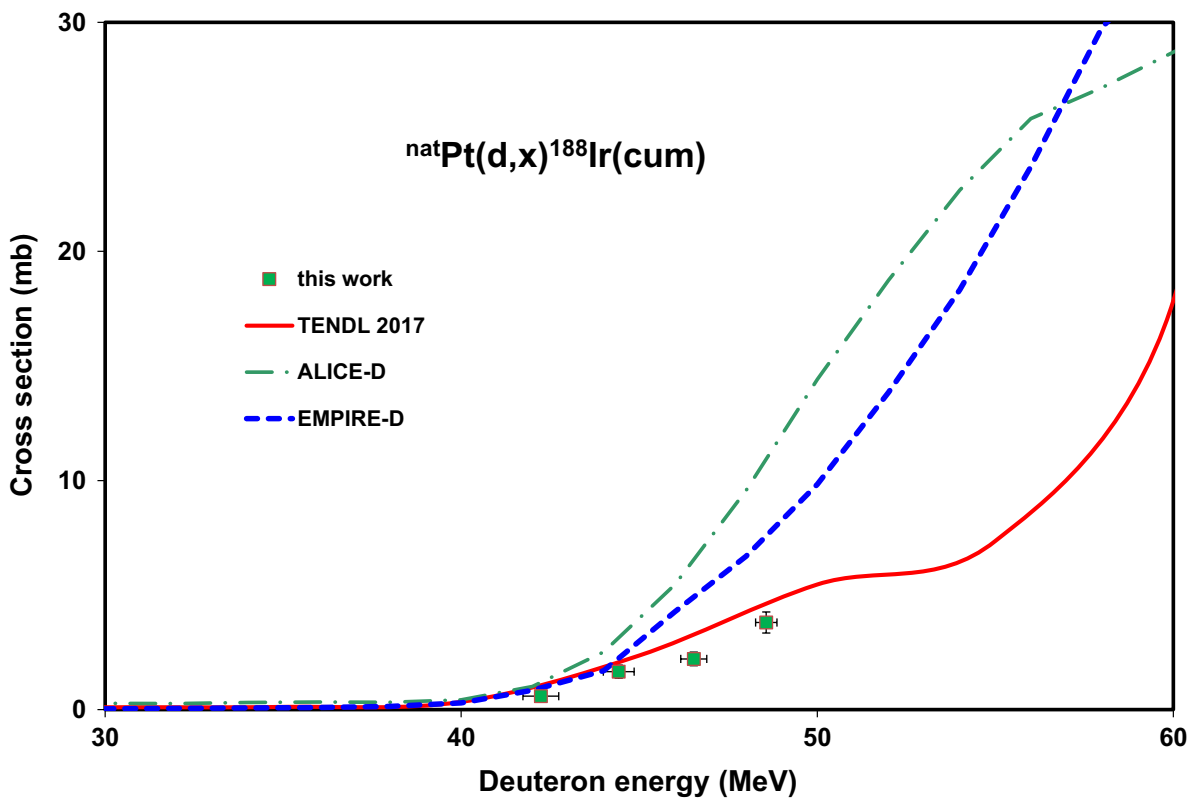

Acknowledgements Open access funding provided by MTA Institute for Nuclear Research (MTA ATOMKI). We thank the Cyclotron Laboratory of the Université Catholique in Louvain la Neuve (LLN) for providing the beam time and the crew of the LLN Cyclone 90 cyclotron for performing the irradiations.

Open Access This article is distributed under the terms of the Creative Commons Attribution 4.0 International License (http://creativeco mmons.org/licenses/by/4.0/), which permits unrestricted use, distribution, and reproduction in any medium, provided you give appropriate credit to the original author(s) and the source, provide a link to the Creative Commons license, and indicate if changes were made.

\section{References}

1. Tárkányi F, Hermanne A, Takács S, Shubin YN, Dityuk AI (2004) Cross sections for production of the therapeutic radioisotopes ${ }^{198} \mathrm{Au}$ and ${ }^{199} \mathrm{Au}$ in proton and deuteron induced reactions on ${ }^{198} \mathrm{Pt}$. Radiochim Acta 92(4-6):223-228

2. Tárkányi F, Takács S, Ditrói F, Csikai G, Hermanne A, Uddin MS, Hagiwara M, Baba M, Shubin YN, Dityuk AI (2001) Measurement of activation cross sections of the proton, deuteron, and alpha particle-induced nuclear reactions on platinum. In: Haight RC, Talou P, Kawano T (eds) International conference on nuclear data for science and technology, Santa Fe, USA, 2004. AIP, pp 1015-1018

3. Tárkányi F, Takács S, Ditrói F, Hermanne A, Shubin YN, Dityuk AI (2004) Activation cross-sections of deuteron induced reactions on platinum. Nucl Instrum Methods Phys Res, Sect B 226(4):490498. https://doi.org/10.1016/j.nimb.2004.06.043

4. Ditrói F, Tárkányi F, Csikai J, Uddin MS, Hagiwara M, Baba M, Shubin YN, Kovalev SF (2006) Excitation functions of long lived products in deuteron induced nuclear reactions on platinum up to $40 \mathrm{MeV}$. Nucl Instrum Methods Phys Res, Sect B 243(1):20-27. https://doi.org/10.1016/j.nimb.2005.07.206

5. Tárkányi F, Ditrói F, Takács S, Csikai J, Hermanne A, Uddin MS, Hagiwara M, Baba M, Shubin YN, Dityuk AI (2004) Activation cross-sections of light ion induced nuclear reactions on platinum: proton induced reactions. Nucl Instrum Methods Phys Res, Sect B 226(4):473-489. https://doi.org/10.1016/j.nimb.2004.06.042

6. Ditroi F, Tarkanyi F, Takacs S, Hermanne A (2017) Extension of activation cross section data of long lived products in deuteron induced nuclear reactions on platinum up to $50 \mathrm{MeV}$. Nucl Instrum Methods Phys Res, Sect B 401:56-70. https://doi. org/10.1016/j.nimb.2017.04.073

7. Hermanne A, Ignatyuk AV, Capote R, Carlson BV, Engle JW, Kellett MA, Kibedi T, Kim G, Kondev FG, Hussain M, Lebeda O, Luca A, Nagai Y, Naik H, Nichols AL, Nortier FM, Suryanarayana SV, Takacs S, Tarkanyi FT, Verpelli M (2018) Reference cross sections for charged-particle monitor reactions. Nucl Data Sheets 148:338-382. https://doi.org/10.1016/j.nds.2018.02.009

8. Tárkányi F, Ditrói F, Takács S, Hermanne A, Ignatyuk AV (2019) Extension of experimental activation cross-sections database of deuteron induced nuclear reactions on manganese up to $50 \mathrm{MeV}$. J Radioanal Nucl Chem 320(1):145-152. https://doi.org/10.1007/ s10967-019-06423-x

9. Canberra (2000) http://www.canberra.com/products/radiochemi stry_lab/genie-2000-software.asp. 2013

10. Székely G (1985) Fgm - a flexible gamma-spectrum analysis program for a small computer. Comput Phys Commun 34(3):313324. https://doi.org/10.1016/0010-4655(85)90008-6

11. NuDat2 database (2.6) (2014) National Nuclear Data Center, Brookhaven National Laboratory. http://www.nndc.bnl.gov/nudat 2/

12. Q-value calculator (2003) NNDC, Brookhaven National Laboratory. http://www.nndc.bnl.gov/qcalc

13. International-Bureau-of-Weights-and-Measures (1993) Guide to the expression of uncertainty in measurement, 1st edn. International Organization for Standardization, Geneva

14. Andersen HH, Ziegler JF (1977) Hydrogen stopping powers and ranges in all elements. In: The stopping and ranges of ions in matter, vol 3. Pergamon Press, New York

15. Tárkányi F, Szelecsényi F, Takács S (1991) Determination of effective bombarding energies and fluxes using improved stackedfoil technique. Acta Radiol Suppl 376:72

16. Dityuk AI, Konobeyev AY, Lunev VP, Shubin YN (1998) New version of the advanced computer code ALICE-IPPE. INDC (CCP)-410. IAEA, Vienna 
17. Herman M, Capote R, Carlson BV, Oblozinsky P, Sin M, Trkov A, Wienke H, Zerkin V (2007) EMPIRE: nuclear reaction model code system for data evaluation. Nucl Data Sheets 108(12):26552715. https://doi.org/10.1016/j.nds.2007.11.003

18. Ignatyuk AV (2010) 2nd RCM on FENDL-3. IAEA. http://wwwnds.iaea.org/fendl3/RCM2_slides.html. 2015

19. Belgya T, Bersillon O, Capote R, Fukahori T, Zhigang G, Goriely S, Herman M, Ignatyuk AV, Kailas S, Koning A, Oblozinsky P, Plujko V, Young P (2005) Handbook for calculations of nuclear reaction data: reference Input Parameter Library. IAEA, Viennahttp://www-nds.iaea.org/RIPL-2/

20. Koning AJ, Rochman D, Sublet JC (2017) TENDL-2017 TALYSbased evaluated nuclear data library, https://tendl.web.psi.ch/tendl 2017/tendl2017.html. 2018

21. Koning AJ, Rochman D (2012) Modern nuclear data evaluation with the TALYS code system. Nucl Data Sheets 113:2841-3172. https://doi.org/10.1016/j.nds.2012.11.002
22. Capote R, Herman M, Oblozinsky P, Young PG, Goriely S, Belgya T, Ignatyuk AV, Koning AJ, Hilaire S, Plujko VA, Avrigeanu M, Bersillon O, Chadwick MB, Fukahori T, Ge Z, Han Y, Kailas S, Kopecky J, Maslov VM, Reffo G, Sin M, Soukhovitskii ES, Talou P (2009) Reference input parameter library (RIPL-3). Nucl Data Sheets 110(12):3107-3214. https://doi.org/10.1016/j. nds.2009.10.004

23. Perey FG (1963) Optical-model analysis of proton elastic scattering in the range of 9 to $22 \mathrm{MeV}$. Phys Rev 131:745

24. Tárkányi F, Ditrói F, Hermanne A, Takács S, Király B, Yamazaki H, Baba M, Mohammadi A, Ignatyuk AV (2011) Activation crosssections of deuteron induced nuclear reactions on gold up to 40 MeV. Nucl Instrum Methods Phys Res, Sect B 269(12):13891400. https://doi.org/10.1016/j.nimb.2011.03.019

Publisher's Note Springer Nature remains neutral with regard to jurisdictional claims in published maps and institutional affiliations. 